\title{
Biotic stress: a significant contributor to organic aerosol in Europe?
}

\author{
R. Bergström ${ }^{1,2}$, M. Hallquist ${ }^{1}$, D. Simpson ${ }^{3,4}$, J. Wildt ${ }^{5}$, and T. F. Mentel ${ }^{6}$ \\ ${ }^{1}$ Department of Chemistry and Molecular Biology, University of Gothenburg, 41296 Gothenburg, Sweden \\ ${ }^{2}$ Swedish Meteorological and Hydrological Institute, 60176 Norrköping, Sweden \\ ${ }^{3}$ EMEP MSC-W, Norwegian Meteorological Institute, Oslo, Norway \\ ${ }^{4}$ Dept. Earth \& Space Sciences, Chalmers University of Technology, Gothenburg, Sweden \\ ${ }^{5}$ Institut für Bio- und Geowissenschaften, IBG-2, Forschungszentrum Jülich, Germany \\ ${ }^{6}$ Institut für Energie- und Klimaforschung, IEK-8, Forschungszentrum Jülich, Germany
}

Correspondence to: T. F. Mentel (t.mentel@fz-juelich.de)

Received: 14 March 2014 - Published in Atmos. Chem. Phys. Discuss.: 26 May 2014

Revised: 16 October 2014 - Accepted: 14 November 2014 - Published: 20 December 2014

\begin{abstract}
We have investigated the potential impact on organic aerosol formation from biotic stress-induced emissions (SIE) of organic molecules from forests in Europe (north of lat. $45^{\circ} \mathrm{N}$ ). Emission estimates for sesquiterpenes (SQT), methyl salicylate (MeSA) and unsaturated $\mathrm{C}_{17}$ compounds, due to different stressors, are based on experiments in the Jülich Plant Atmosphere Chamber (JPAC), combined with estimates of the fraction of stressed trees in Europe based on reported observed tree damage.

SIE were introduced in the EMEP MSC-W chemical transport model and secondary organic aerosol (SOA) yields from the SIE were taken from the JPAC experiments. Based on estimates of current levels of infestation and the JPAC aerosol yields, the model results suggest that the contribution to SOA in large parts of Europe may be substantial. It is possible that SIE contributes as much, or more, to organic aerosol than the constitutive biogenic VOC emissions, at least during some periods. Based on the assumptions in this study, SIE-SOA are estimated to constitute between 50 and $70 \%$ of the total biogenic SOA (BSOA) in a current-situation scenario where the biotic stress in northern and central European forests causes large SIE of MeSA and SQT. An alternative current-situation scenario with lower SIE, consisting solely of SQT, leads to lower SIE-SOA, between 20 and $40 \%$ of the total BSOA.

Hypothetical future scenarios with increased SIE, due to higher degrees of biotic stress, show that SOA formation due to SIE can become even larger.

Unsaturated $\mathrm{C}_{17}$ BVOC (biogenic volatile organic compounds) emitted by spruce infested by the forest-honey generating bark louse, Cinara pilicornis, have a high SOA-
\end{abstract}

forming potential. A model scenario investigating the effect of a regional, episodic infestation of Cinara pilicornis in Baden-Württemberg, corresponding to a year with high production of forest honey, shows that these types of events could lead to very large organic aerosol formation in the infested region.

We have used the best available laboratory data on biotic SIE applicable to northern and central European forests. Using these data and associated assumptions, we have shown that SIE are potentially important for SOA formation but the magnitude of the impact is uncertain and needs to be constrained by further laboratory, field and modelling studies. As an example, the MeSA, which is released as a consequence of various types of biotic stress, is found to have a potentially large impact on SIE-SOA in Europe, but different assumptions regarding the nighttime chemistry of MeSA can change its SOA potential substantially. Thus, further investigations of the atmospheric chemistry of MeSA and observational field studies are needed to clarify the role of this compound in the atmosphere.

\section{Introduction}

The emissions of biogenic volatile organic compounds (BVOC) by forests are the major sources of hydrocarbons to the atmosphere (Guenther et al., 2012; Lamarque et al., 2010; Simpson et al., 1999). Photo-oxidation of BVOC, in the presence of nitrogen oxides $\left(\mathrm{NO}_{\mathrm{x}}\right)$, contributes to the formation of tropospheric ozone and leads to secondary organic 
aerosol (SOA) particle formation (Hallquist et al., 2009). Many BVOC, e.g. isoprene, $\alpha$-pinene, and sesquiterpenes (SQT), are unsaturated and react with all main oxidants in the atmosphere $\left(\mathrm{OH}\right.$, ozone and $\left.\mathrm{NO}_{3}\right)$, while the saturated BVOC preferably react with $\mathrm{OH}$. SOA formation is caused by the gas-to-particle transformation of some of the oxidation products, depending on, for example their vapour pressure. Studies using carbon-14 and other tracer compounds have shown that such biogenic SOA (BSOA) is often the major contributor to ambient organic aerosols $(\mathrm{OA})$ at rural, and even some urban, sites in Europe (Gelencsér et al., 2007; Minguillon et al., 2011; Szidat et al., 2004, 2009; Yttri et al., 2011).

BSOA formation can play an important (but complex) role in the radiation balance of the Earth, and thus for surface temperature (Arneth et al., 2010). In a future climate, vegetation growth may increase in many areas, especially in the boreal and temperate regions (e.g. Ahlström et al., 2012; Morales et al., 2007; Lathiere et al., 2005), with possible increases in BVOC emissions because of increasing foliar expansion and increasing temperatures (Lathiere et al., 2005; Guenther et al., 2006, 2012; Duhl et al., 2008; Arneth et al., 2011). Increased BVOC emissions will result in more and larger atmospheric particles (Joutsensaari et al., 2005; Allan et al., 2006; VanReken et al., 2006; Tunved et al., 2008; Mentel et al., 2009; Riipinen et al., 2011).

The emissions of BVOC are regarded as being "constitutive" if produced and released in the unperturbed, nonstressed state of the vegetation. In BVOC-emission algorithms, the constitutive emissions are assumed to be under the control of meteorological factors, especially temperature and light, as well as phenological cycles (Guenther et al., 2012). The SOA forming potential of these emissions, especially isoprene and monoterpenes (MT), and to a lesser extent SQT, have been extensively investigated in laboratory studies over many years (e.g. Bonn and Moortgat, 2003; Lee et al., 2006; Hallquist et al., 2009, and references therein; Winterhalter et al., 2009; Donahue et al., 2012; Jaoui et al., 2013).

Algorithms derived from such laboratory data have been applied in atmospheric chemical transport models (CTMs), using a variety of techniques to treat BVOC emissions, chemistry and gas-particle partitioning (Bowman et al., 1997; Andersson-Sköld and Simpson, 2001; Schell et al., 2001; Kanakidou et al., 2005; Donahue et al., 2006, 2009; Simpson et al., 2007; Kroll and Seinfeld, 2008; Hallquist et al., 2009; Jimenez et al., 2009; Murphy and Pandis, 2009; Bergström et al., 2012; Li et al., 2013). For many years OA and SOA were largely underestimated by some CTMs compared to field observations (Heald et al., 2005; Kanakidou et al., 2005; Volkamer et al., 2006). This gap has been reduced in recent years, partly by improved gas-particle mechanisms considering higher generations of oxidation products of VOC as SOA sources, i.e. chemical ageing (Donahue et al., 2006, 2009, 2012). Indeed there are indications that with simplified models for ageing chemistry (lacking fragmentation reactions) newer schemes can even overestimate SOA in some cases (e.g. Bergström et al., 2012; Lane et al., 2008).

Still, with the exception of Berg et al. (2013), all model studies to date, that we are aware of, have only considered the standard constitutive emissions discussed above. Besides constitutive emissions, vegetation also releases so-called induced emissions into the atmosphere. Induced emissions are often caused by "biotic stress" - by infestation of insects, viruses, fungi, etc. (e.g. Arneth and Niinemets, 2010; Amin et al., 2012, 2013; Berg et al., 2013), but they are also affected by other stressors like heat or drought (e.g. Kleist et al., 2012). In this paper we will collectively denote these emissions as stress-induced emissions (SIE).

Berg et al. (2013) investigated the impact of bark beetle infestations on MT emissions and SOA formation in western North America. MT emissions due to bark beetles may both increase (during attack) and decrease (after tree death), and Berg et al. found that beetle infestations in pine trees can have a significant regional impact on SOA concentrations (up to $40 \%$ increase) during some years; responses may be substantially larger if spruce trees are infested (Berg et al., 2013).

Recently, SOA mass yields from the laboratory studies in the Jülich Plant Atmosphere Chamber (JPAC), with real plants as sources, showed that terpenoidic SIE, such as sesquiterpenes, and phenolic BVOC (e.g. methyl salicylate, MeSA), originating downstream of the shikimate pathway (e.g. Wildermuth, 2006), are very efficient in forming SOA (Mentel et al., 2013). Their particle mass yields are 3-4 times larger than those of MT, see Sect. 2.2. In a case where a spruce was infested by Cinara pilicornis (honeydew-generating lice) unsaturated $\mathrm{C}_{17}$ BVOC (mainly 8-heptadecene, 6,9-heptadecadiene, and 3,6,9-heptadecatriene) were observed with particle mass yields 6 times higher than those of MT (Mentel et al., 2013). Given that SIE are a ubiquitous source of BVOC and thus SOA in forests, these laboratory findings suggest that SIE may account for a significant fraction of ambient SOA mass. Neglect of the SIE in models might explain some of the discrepancies between observed OA and model predictions.

If the SIE increase in the future (e.g. with increasing frequencies of insect damage, Jonsson et al., 2009), the SIESOA concentrations will also rise; and indeed the role of SIE in a changing climate is attracting increasing attention (Peñuelas and Staudt, 2010; Holopainen, 2011). Even current-condition SIE, due to, for example, biotic stressors, are difficult to assess; inherent difficulties include the episodic character and time lags of the emissions, dependencies on plant history, and adaption to stresses, as well as the scaling of emissions from leaf level to regional scale (Arneth and Niinemets, 2010; Niinemets et al., 2010). All of these aspects require substantial research, and, as discussed by Arneth and Niinemets (2010), building modules that simulate induced emissions is a difficult if not impossible task at the current level of understanding. 
SIE are generally not explicitly included in atmospheric models because of (i) a lack of awareness of their possible importance, (ii) a lack of suitable data and information about the distribution of stress and its specific effects, and (iii) a lack of appropriate SOA formation algorithms. However, given these difficulties, it is still appropriate and important to assess the order of magnitude of such SIE-SOA contributions to ambient aerosol. Here we want to demonstrate how the neglect of SIE in models may affect current SOA predictions and the possible effects of SIE on SOA in the future.

The goal of this model study is to draw attention to the possible importance of SIE emissions, and to make a first estimate of their contribution to SOA formation (both in current conditions and with a projection of what could happen in the future under the assumption that stress to plants becomes more frequent or severe). We combine experimental emission and SOA formation results from JPAC with estimates of the possible geographical extent of the SIE, and use the EMEP MSC-W regional chemical transport model (Simpson et al., 2012; Bergström et al., 2012) to assess potential SOA formation over Europe. To construct continental scale emission scenarios for the SIE, we make use of European and national forest damage reports. These are in general based on ocular inspection of defoliation and insect infestation in European forests; the inspections are performed regularly and follow well defined protocols (Lorenz, 2010; Ferretti et al., 2010).

A major strength of this study is that both the emission factors of SIE/constitutive emissions and SIE-SOA mass yields are determined from the same experimental JPAC data for relevant forest species. As shown for new particle formation and SOA yields the results from the JPAC studies can be transferred to atmospheric situations (Mentel et al., 2009). Uncertainties arise from the estimates of the fraction and spatial distribution of infested trees, as well as limited knowledge of the seasonal variation of some of the infestations. Despite these uncertainties, this work, by use of selected scenarios, clearly shows that SIE and SIE-SOA deserve closer consideration as potentially significant sources of organic aerosol in Europe.

\section{Methods}

This model sensitivity study of potential effects of biotic SIE is based on the following: (1) evaluation of experimentally observed BVOC emissions by insect-infested plants and their photochemical conversion to SOA, (2) estimation of the potential fraction of infested trees in European forests, and (3) construction of future scenarios with increased fractions of infested trees. The stepwise procedure employed in the present study is described in detail below and a summary of the resulting model scenarios is given in Table 1.

\subsection{Experimental}

SOA mass yields and emission ratios were determined in the same experiments in the JPAC as published in Mentel et al. (2013). In short, JPAC consists of three continuously stirred flow reactors, made of Borosilicate glass, which are placed in temperature controlled housings. One of these is operated as a reaction chamber and SOA is formed therein by photooxidation and ozonolysis products (Mentel et al., 2009). One of the other chambers serves as plant chamber and house the plants under controlled conditions. The plant chamber is permanently flushed with clean air to which $\mathrm{CO}_{2}$ and water vapour are added. A fraction of the outflow of the plant chamber is led into the reaction chamber; ozone and water vapour are added by a second stream. Switching on a UV lamp $\left(\lambda_{\max }=254 \mathrm{~nm}\right)$ initializes the photochemistry. The strength and pattern of the plant emissions are measured by GC-MS (e.g. Kleist et al., 2012) in the outflow of the plant chamber, i.e. in absence of oxidants and chemical reactions. For the emission factors applied here, the concentrations of MT and the respective SIE in the outgoing airstream of the plant chamber were averaged for the same time intervals as in which the SIE-SOA mass yields were determined.

\subsection{BVOC emission factors for infested trees}

In order to keep our model results transparent, we used a simplified direct approach for preparing the model emission scenarios. We used the standard EMEP emissions for monoterpenes (Simpson et al., 2012) and applied emission ratios for SIE/MT based on experimental data from JPAC (Mentel et al., 2013) to set the SIE in the model. The SIE considered here (SQT and MeSA) are of de novo type (Kleist et al., 2012), i.e. they are emitted in connection with biosynthetic production.

Monoterpene emissions (from storage pools) are often increased due to plant stress (especially as a consequence of mechanical wounding; Juuti et al., 1990, Schade and Goldstein, 2003, Haase et al., 2011, Kaser et al., 2013). However in this study all MT emissions were assigned to the constitutive emissions, based on the fact that the MT emissions measured during the JPAC experiments were quite similar to those measured for unstressed plants of the same species.

The emission ratios were determined in JPAC under steady state conditions as described above. The direct use of JPACderived data for application or extrapolation to ambient conditions has been confirmed in earlier studies for particle formation rates and SOA mass yields for boreal tree species (Mentel et al., 2009), the chemical composition of the resulting SOA (Kiendler-Scharr et al., 2009b), interaction of isoprene and MT emissions (Kiendler-Scharr et al., 2009a), and the distribution of highly oxidized aerosol precursors (Ehn et al., 2012). The use of real plant emissions and close to ambient concentrations make us think that the laboratory- 
Table 1. Biotic stress-induced emissions (SIE) of sesquiterpenes (SQT), methyl salicylate (MeSA) and unsaturated $\mathrm{C}_{17} \mathrm{BVOC}(\mathrm{C} 17)$ in the different model scenarios. The SIE are expressed as fractions of the daytime model emissions of monoterpenes (MT).

\begin{tabular}{llccc}
\hline Scenario (notes, exp.) & Area & SQT/MT & MeSA/MT & C17/MT \\
\hline Case $0^{\mathrm{a}}$ & everywhere & $0.05^{\mathrm{e}}$ & - & - \\
${\text { Case } 1^{\mathrm{b}}}^{\mathrm{L}}$ & 0.24 & - & - \\
& $45^{\circ} \mathrm{N}<\mathrm{Lat} \leq 60^{\circ} \mathrm{N}$ & 0.48 & - & - \\
& Lat $\leq 45^{\circ} \mathrm{N}$ & 0.05 & - & - \\
Case $2^{\mathrm{c}}$ & Lat $>60^{\circ} \mathrm{N}$ & 0.49 & 0.35 & - \\
& $45^{\circ} \mathrm{N}<\mathrm{Lat} \leq 60^{\circ} \mathrm{N}$ & 0.98 & 0.70 & - \\
& Lat $\leq 45^{\circ} \mathrm{N}$ & 0.05 & - & - \\
Case $1 \mathrm{~F}^{\mathrm{b}}$ & Lat $>60^{\circ} \mathrm{N}$ & 1.2 & - & - \\
& $45^{\circ} \mathrm{N}<\mathrm{Lat} \leq 60^{\circ} \mathrm{N}$ & 1.6 & - & - \\
& Lat $\leq 45^{\circ} \mathrm{N}$ & 0.05 & - & - \\
Case $2 \mathrm{~F}^{\mathrm{c}}$ & Lat $>60^{\circ} \mathrm{N}$ & 2.45 & 1.75 & - \\
& $45^{\circ} \mathrm{N}<$ Lat $\leq 60^{\circ} \mathrm{N}$ & 3.27 & 2.33 & - \\
& Lat $\leq 45^{\circ} \mathrm{N}$ & 0.05 & - & - \\
Case $3^{\mathrm{d}}$ & Jun-Jul, Lat: $47.8-49.8^{\circ} \mathrm{N}$, & 0.38 & - & 6.8 \\
& Lon: $8.0-10.2^{\circ} \mathrm{E}$ & & & - \\
\hline
\end{tabular}

Notes: The model scenarios are based on the following JPAC chamber experiments a Mentel et al. (2009); ${ }^{\text {b }}$ Exp. 2 in Mentel et al. (2013); ${ }^{\mathrm{c}}$ Exp. 1 in Mentel et al. (2013); ${ }^{\mathrm{d}}$ Exp. 3 in Mentel et al. (2013). ${ }^{\mathrm{e}}$ SQT emissions from unstressed plants are set to $5 \%$ of the MT emissions.

derived data from JPAC provide the best-available estimate of SIE-SOA yields for our purposes.

From the observations by Mentel et al. (2013), we constructed three biotic stress scenarios. Case 1 treats aphid infestation with enhanced SQT emissions with SQT/MT $=2.4$ (mass based ratios). Case 2 covers aphid infestations which caused enhanced emissions of SQT $(\mathrm{SQT} / \mathrm{MT}=4.9)$ and triggered MeSA emissions via the shikimate pathway $(\mathrm{MeSA} / \mathrm{MT}=3.75)$. Case 1 and Case 2 were assumed to be typical for all trees of boreal and central European forests. As the SIE emissions studied here are of de novo type, they were only switched on during daytime.

A further Case 3 was constructed from an experiment investigating infestation of a spruce by Cinara pilicornis, which led to strong emissions of several unsaturated linear $\mathrm{C}_{17} \mathrm{BVOC}$ with an emission factor $\mathrm{C}_{17} \mathrm{BVOC} / \mathrm{MT}=18$. Mentel et al. (2013) did not determine whether the $\mathrm{C}_{17}$ compounds originated from the plant or the infesting insects; the $\mathrm{C}_{17}$ BVOC emissions were considered as originating from the coupled plant-insect system.

The louse under consideration here, Cinara pilicornis, belongs to the family of bark lice that produce honeydew, which is collected by bees. Such bark lice are of economic interest for beekeepers; observations by beekeepers in BadenWürttemberg (BW), in south-west Germany, show that such infestations (or more precisely the honey production from Cinara pilicornis and similar infestations) vary strongly from year to year and have high seasons during June/July (http: //www.stockwaage.de/). Accordingly we constructed a SIE emission pulse of $\mathrm{C}_{17} \mathrm{BVOC}$, which was limited in time and spatial extension. As the $\mathrm{C}_{17}$ BVOC emissions in JPAC were
2-3 times larger at daytime than during night, we switched them on only during daytime in the model, like the other two SIE.

Mentel et al. (2013) focused on tree species from the boreal region and from central Europe. Therefore, we have focused our analysis on northern and central Europe, and implement SIE for areas north of lat. $45^{\circ} \mathrm{N}$, although it may be assumed that stress also affects the emissions from plants growing in other regions.

\subsection{Estimation of fraction of infested trees}

Since the observed emission factors only consider infested trees, the fraction of infested trees has to be estimated. It is difficult to estimate the degree of insect infestations on larger scales in real forests. In the present study we chose a relatively simple approach to make what we believe to be a rough but reasonable estimate of the present-day situation. We base the estimate on regular surveys of the European forests. ICP Forests (the International Co-operative Programme on Assessment and Monitoring of Air Pollution Effects on Forests operating under the UNECE Convention on Long-range Transboundary Air Pollution) provides annual executive reports on the conditions of the forests in $\mathrm{Eu}-$ rope (http://www.icp-forests.org/); they also publish reports of the national member forest agencies. From these, Fischer et al. (2012) provide details of tree crown damage and defoliation in many European countries; they report that a fifth of all trees are rated as damaged and that "defoliation represents a valuable early warning system for the response of forest ecosystems to different stress factors". They also re- 


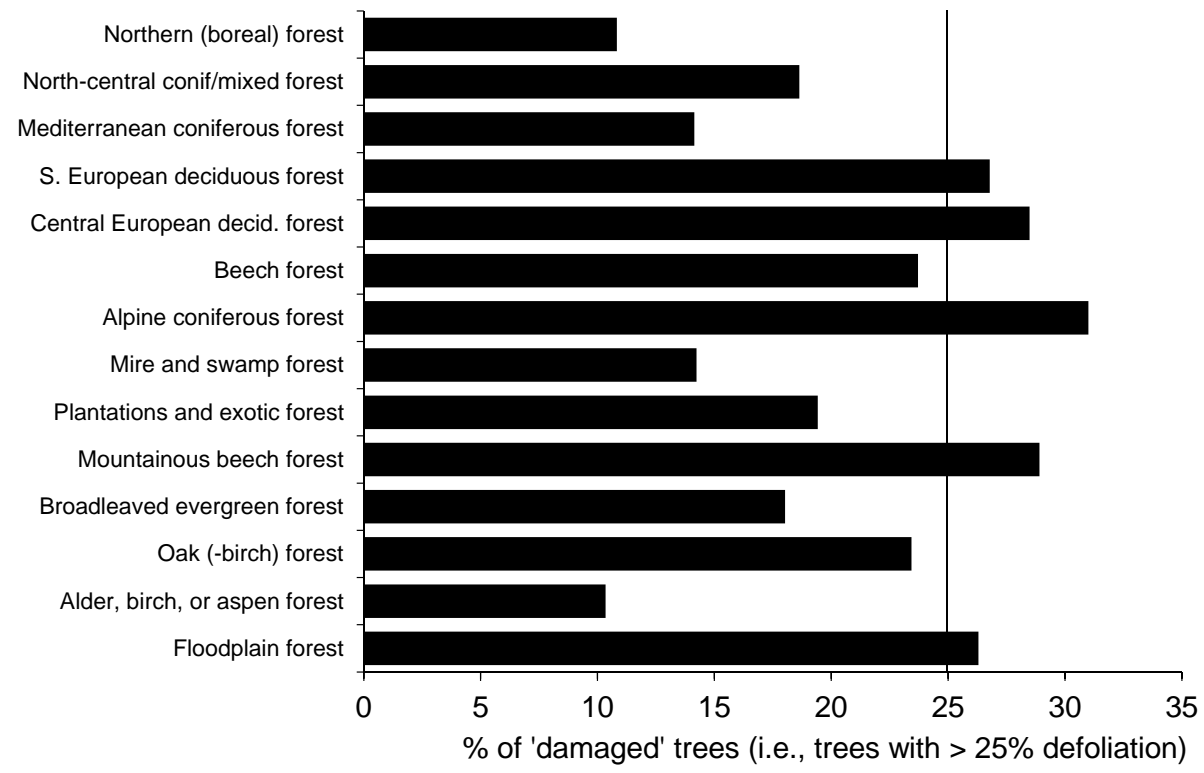

Figure 1. Fraction $(\%)$ of damaged trees ( $>25 \%$ defoliation) in different European forest ecosystems. The top two bars refer to the main forest types investigated in the present study. (Figure adapted from ICP Forests, Fischer et al., 2012, used with permission.)

port that insects are the most frequent cause of damage to trees in Europe.

Relatively large fractions of the northern and central European trees show a significant degree of defoliation ( $>25 \%$, rated as damaged by Fischer et al., 2012); the fractions of damaged trees are $11 \%$ for northern boreal forests, $19 \%$ for north-central coniferous/mixed forests (e.g. Germany and southern Sweden), $28 \%$ for central European deciduous forests, and $24 \%$ for beech forests, as can be seen in the top two bars and 4th to 5th bar of Fig. 1. We suggest that the reported defoliation damage can be used as a measure of stress effects. The applicability of our assumption is supported by the large European forest survey 2010 (ICP Forests, 2011), which found that insects are the greatest cause of damage to trees; $17 \%$ of all investigated trees were damaged by insects (corresponding to $27 \%$ of the total number of damaged trees). For comparison, about $10 \%$ of the trees were damaged by "fungi" and ca $9 \%$ by abiotic factors (e.g. drought and frost) (for more details about different damaging agents see Fig. 2-5, in ICP Forests, 2011).

Insect infestations are well distributed over northern and central European forests as shown by Fischer et al. (2012) (see their Fig. 2-3). For the boreal forests, the Finnish forest damage report from Merilä et al. (2007) stated that about 10$12 \%$ of the pines showed a significant degree of defoliation (>25\%). Similarly to the European situation, about the same order of trees (about $10 \%$ ) showed damage caused by insects and fungi, with in general more being caused by fungi. By combining these two types of forest observations, we conclude for our cases that the fraction of trees with significant defoliation $(>25 \%)$ may serve as a first order approach to assess the fraction of stressed trees in the current situation. Consequently, we adopt these numbers and assume that the fraction of currently stress-affected trees is $10 \%$ for latitudes greater than $60^{\circ} \mathrm{N}$ and $20 \%$ between $45^{\circ} \mathrm{N}$ and $60^{\circ} \mathrm{N}$. This will constitute our base case for impact of contemporary SIE (Case 1 and Case 2).

\subsubsection{Increased degree of infestation - possible future scenarios?}

For the future scenarios our hypothesis is that the degree of infestation may increase if the climate changes unfavourably for an established vegetation. Considering that the knowledge about the present-day degree of infestation is limited, it is even more problematic to describe how SIE will develop in the future. However, we use a similar approach as for the current situation, but take it a step further and assume that insect infestations may affect trees that today are at the next reported degree of defoliation (greater than $10 \%$ ). This will then include about $2 / 3$ of the trees in central Europe (Fischer et al., 2012) and about $50 \%$ of the trees in the boreal forests (Finnish National Report 2007: Merilä et al., 2007). This may be considered as a severe-case scenario of a possible future. These high degrees of infestation were used to illustrate how severe biotic stress can enhance SIE and contribute to SOA, and we address these as two extreme future scenarios, Case $1 \mathrm{~F}$ and $2 \mathrm{~F}$. Given the uncertainty of estimating future SIE emissions, the MT emissions were, for the sake of simplicity, kept at the current level. 


\subsubsection{Regional episodic infestation by bark lice}

The construction of Case 3 with $\mathrm{C}_{17}$ BVOC emission from the Cinara pilicornis infestation is somewhat more indirect. Here we make use of the fact that the honeydew produced by Cinara pilicornis (and other bark lice) is a source of a certain kind of honey: the forest honey. Detailed observational data on forest-honey production exist in Baden-Württemberg (see http://www.stockwaage.de/), so we selected this region of south-west Germany for an episodic test case. The relation between infestation and forest-honey production is well known to beekeepers (e.g. see http://stockwaage.de/) and from their statistics we can extract the seasonality and the annual variation of the forest-honey production as related to Cinara pilicornis infestation. In a good honey year the infestation is widespread, even if there are some local variations, and lasts through the summer months.

Since Mentel et al. (2013) observed $\mathrm{C}_{17}$ BVOC emission from the Cinara pilicornis / Norway spruce system, we assume for simplicity that all spruce in BW are infested and the resulting SIE occur during the months June and July, with the given $\mathrm{C}_{17} \mathrm{BVOC} / \mathrm{MT}$ ratio of 18 . The forests in BW consist of $38 \%$ spruce (http://www.mlr.baden-wuerttemberg.de/ Die_Baumarten/507.html). Other conifers, mainly fir and pine, make up another $19 \%$ of the forest. The rest are broadleaf species mainly beech $(21 \%)$ and oak $(7 \%)$. This causes a small flaw in our concept of applying the emission ratios as observed in JPAC, as the emission strength of spruce and the other conifers and specifically of the broadleaf species may be different. For simplicity, we assume that during an active year all spruce are affected and that these also accounts for $38 \%$ of the emissions. As a consequence, the $\mathrm{C}_{17} \mathrm{BVOC} / \mathrm{MT}$ emission ratio from the JPAC experiment is weighted by a factor of 0.38 in BW. Although the assumption that all spruce trees in BW are heavily infested may be viewed as an extreme case, we note that other tree species may also be simultaneously infested by lice and, on the beekeeper web page http://stockwaage.de/index.php/rueckblick, there is indeed a year described (2006) when lice even infested deciduous trees and contributed to honeydew production.

\subsection{The EMEP MSC-W model}

The standard EMEP MSC-W chemical transport model has been described in detail by Simpson et al. (2012); a research version of the model (Bergström et al., 2012), with extended treatment of particulate carbonaceous matter, has been used in the present study. The EMEP MSC-W model is a development of the 3-D CTM of Berge and Jakobsen (1998), extended with photo-oxidant and aerosol chemistry. The model domain used in this study covers the whole of Europe, and includes a large part of the North Atlantic and Arctic areas. The standard grid system of the model is based on a polar stereographic projection, with a horizontal res- olution of ca. $50 \mathrm{~km} \times 50 \mathrm{~km}$ at latitude $60^{\circ} \mathrm{N}$. The model includes 20 vertical layers, using terrain-following coordinates, and the lowest layer has a thickness of about $90 \mathrm{~m}$. The model has been extensively compared with measurements of many different compounds (e.g. Jonson et al., 2006; Simpson et al., 2006; Fagerli and Aas, 2008; Aas et al., 2012; Bergström et al., 2012; Sakalli and Simpson, 2012; Genberg et al., 2013; Gauss et al., 2014). For short-lived radicals, evaluation against measurements is problematic for regional scale CTMs. The EMEP MSC-W chemical mechanism has been shown to provide results for $\mathrm{OH}$ and $\mathrm{NO}_{3}$ in line with other (more detailed) models (Andersson-Sköld and Simpson, 1999; Kuhn et al., 1998; Karl et al., 2014). Model results for $\mathrm{NO}_{3}$ are discussed further in Sect. 3.3. For the present study meteorological data from the European Centre for Medium Range Weather Forecasting Integrated Forecasting System (ECMWF-IFS) model (http://www.ecmwf. int/research/ifsdocs/) were used; all simulations were performed for the (meteorological) year 2007.

This study focuses on OA from biogenic emissions. The constitutive emissions of monoterpenes and isoprene are calculated in the model, using near-surface air temperature $\left(T_{2} \mathrm{~m}\right)$ and photosynthetically active radiation. Standard condition emission factors for forests are based on tree species specific monoterpene emission factors for 115 different tree species, combined with detailed maps of the distribution of the trees in Europe, as described by Simpson et al. (2012). Such emissions are of course very uncertain given the lack of underlying measurements for European ecosystems, as discussed in more detail in Simpson et al. $(1999,2012)$ and Keenan et al. (2009), and illustrated for European isoprene emissions (with results from four models) in Langner et al. (2012). The EMEP values are believed to be well grounded in recent reviews of emissions rates (Simpson et al., 2012).

As with most BVOC emission databases, the standard EMEP system does not explicitly include SIE emissions. Sesquiterpene emissions were also deliberately omitted in earlier studies because it was judged that the emission rates and underlying emission algorithms were too uncertain compared to even those of isoprene and monoterpenes (e.g. Duhl et al., 2008). Other models do include some sesquiterpene emissions, but with the assumption that these are a fraction of the normal constitutive emissions (e.g. Fountoukis et al., 2011; Aksoyoglu et al., 2011). Some level of SIE may be included in the emission measurements which underlie the BVOC emission factors inventories used. To our knowledge, no other CTM has so far treated SIE-SOA production from MeSA or the $\mathrm{C}_{17}$ BVOC included in the present study.

All SOA in this work is assumed to be formed through gas-particle partitioning to the accumulation mode, which in the EMEP MSC-W model has a mass-median diameter of $330 \mathrm{~nm}$. This assumption is consistent with many studies over Europe and at Hyytiälä (e.g. Allan et al., 2006; Beddows et al., 2014). This means that the difference between OA in $\mathrm{PM}_{1}$ and $\mathrm{PM}_{2.5}$ is negligible in the model. 
Some updates have been done to the model, compared to Bergström et al. (2012). As in the standard EMEP model (Simpson et al., 2012), emissions from open biomass fires were taken from the FINNv1 inventory (Wiedinmyer et al., 2011), and hourly variation of anthropogenic emissions were used instead of the simpler day-night system used in earlier EMEP models. For this study, we use updated emissions of primary organic aerosol (POA), with a recently developed inventory for residential combustion of biofuels (Denier van der Gon et al., 2014). In the present study we set the background concentration of organic aerosol to $0.4 \mu \mathrm{g} \mathrm{m}^{-3}$, to prevent an overestimation of OA seen at many sites when using the previous background concentration of $1 \mu \mathrm{g} \mathrm{m}^{-3}$ (Bergström et al., 2012).

Bergström et al. (2012) implemented and tested a number of different organic aerosol schemes, based on the volatility basis set (VBS) approach. The base case in the present study uses the PAP version (Partitioning and atmospheric Ageing of Primary semi- and intermediate-volatility OC emissions), from Bergström et al. (2012), that distributes the POA emissions over different volatilities and assumes that the POA emissions are accompanied by emissions of intermediate volatility compounds (IVOC) that react with $\mathrm{OH}$ in the atmosphere (as in Shrivastava et al., 2008); this "ageing" transforms the species to lower volatilities that may partition to the particle phase. The base case OA scheme used here is almost identical to the PAP model in Bergström et al. (2012); the only difference is that a small emission of sesquiterpenes is added (equal to $5 \%$, by mass, of the daytime MT emissions) based on observed emissions from plants with no observable biotic stress by Mentel et al. (2009).

Very simplified mechanisms for SOA formation from SQT, MeSA and $\mathrm{C}_{17}$-BVOC were added to the model. Fixed SOA (mass) yields, based on experimental data (Mentel et al., 2013), were used for these three model compounds. Note that the SOA-yield from SQT oxidation (17 mass \%) is based on experimentally determined yields from SQTemissions from aphid-infested Norway Spruce trees (see Mentel et al., 2013); here we assume the same SOA-yield from all SQT-emissions. For MeSA and $\mathrm{C}_{17}$-BVOC the yields are 22 and $33 \%$, respectively:

$$
\begin{array}{r}
\operatorname{SQT}\left(+\mathrm{O}_{\mathrm{x}}\right) \rightarrow 0.17 \text { SQT_SOA }, \\
\operatorname{MeSA}(+\mathrm{OH}) \rightarrow 0.22 \text { MeSA_SOA }, \\
\mathrm{C}_{17}-\mathrm{BVOC}\left(+\mathrm{O}_{\mathrm{x}}\right) \rightarrow 0.33 \mathrm{C}_{17} \text { B_SOA, }
\end{array}
$$

where $\mathrm{Ox}$ is a general oxidant $\left(\mathrm{O}_{3}\right.$ or $\mathrm{OH} ; \mathrm{NO}_{3}$ may also react with SQT, and possibly with $\mathrm{C}_{17}$-BVOC; however, since we only consider daytime SIE in this study, the $\mathrm{NO}_{3}$ reaction is of minor importance compared to the fast $\mathrm{O}_{3}$ and $\mathrm{OH}$ reactions). The parentheses around the oxidants indicate that these oxidants are not depleted in the chemical mechanism. As in Simpson et al. (2012) and Bergström et al. (2012), gas-phase BVOC chemical mechanisms are only available for isoprene, for which the EMEP model traces degradation through species such as methyl-vinyl-ketone, methacrolein and methylglyoxal. Other BVOC species are treated in a very simplified manner, whereby oxidation of the BVOC produces only the compounds specified by the VBS scheme or the fixed-yield non-volatile SIE-SOA components. For such compounds, the chemistry is assumed to be "oxidantneutral"; that is, we assume that as much $\mathrm{O}_{3}$ or $\mathrm{OH}$ is reformed in the neglected part of the chemistry as is consumed in the initial BVOC reactions. This procedure ensures that the ozone chemistry will be the same as in the standard photochemistry version of the EMEP MSC-W model.

SOA-formation from sesquiterpenes is rapid; in the model we use rates based on the $\beta$-caryophyllene chemistry scheme in the Master Chemical Mechanism (MCM v3.2 (Jenkin et al., 2012), via website: http://mcm.leeds.ac.uk/MCM). For the $\mathrm{C}_{17}$ BVOC no kinetic information is available. As observed in JPAC, the $\mathrm{C}_{17}$ BVOC had a short lifetime with respect to oxidation by $\mathrm{O}_{3}$ and $\mathrm{OH}$; for simplification, we therefore applied the same $\mathrm{OH}-$ and $\mathrm{O}_{3}$ reaction-rate coefficients $\left(1.97 \times 10^{-10} \mathrm{~cm}^{3}\right.$ molecule ${ }^{-1} \mathrm{~s}^{-1}$ and $1.16 \times 10^{-14} \mathrm{~cm}^{3}$ molecule ${ }^{-1} \mathrm{~s}^{-1}$, respectively) for the $\mathrm{C}_{17}$ BVOC as for $\beta$-Caryophyllene.

MeSA is much more stable in the atmosphere (Canosa-Mas et al., 2002) and, based on experimental data from JPAC, an OH-reaction-rate coefficient of $4 \times 10^{-12} \mathrm{~cm}^{3}$ molecule ${ }^{-1} \mathrm{~s}^{-1}$ was used. The low reaction rate of MeSA with $\mathrm{OH}$ allows for significant MeSA concentrations during the night and since MeSA is a phenolic compound we must also consider the reaction with $\mathrm{NO}_{3}$ :

$\operatorname{MeSA}\left(+\mathrm{NO}_{3}\right) \rightarrow \alpha$ MeSA_SOA.

The rate of the MeSA $+\mathrm{NO}_{3}$ reaction is not known and neither is the SOA-yield $(\alpha)$ of the reaction; nighttime degradation of MeSA by $\mathrm{NO}_{3}$ reaction could possibly be fast (Canosa-Mas et al., 2002). Canosa-Mas et al. (2002) assumed that MeSA could react as fast with $\mathrm{NO}_{3}$ as phenol does $\left(k=3.8 \times 10^{-12} \mathrm{~cm}^{3}\right.$ molecule $\left.{ }^{-1} \mathrm{~s}^{-1}\right)$; however, the $\mathrm{MeSA}+\mathrm{NO}_{3}$ reaction may be slower, because the MeSA molecule may form an internal hydrogen bond between the $\mathrm{OH}$-hydrogen and the ester group, leading to an increased stability in comparison to phenol. The MeSA $+\mathrm{OH}$ reaction, for example, is 7 times slower than the phenol $+\mathrm{OH}$ reaction (IUPAC: http://www.iupac-kinetic.ch.cam.ac.uk; 2008). Preliminary results from laboratory experiments in JPAC indicate that the $\mathrm{MeSA}+\mathrm{NO}_{3}$ reaction is about an order of magnitude slower than the phenol $+\mathrm{NO}_{3}$ reaction. Details of the measurements regarding the determinations of the rate constants will be published elsewhere.

Therefore, in the present study we used $k=5.4 \times$ $10^{-13} \mathrm{~cm}^{3}$ molecule $\mathrm{s}^{-1} \mathrm{~s}^{-1}$ for the $\mathrm{MeSA}+\mathrm{NO}_{3}$ reaction, which is equal to the phenol $+\mathrm{NO}_{3}$ reaction rate divided by seven (the scaling factor of the $\mathrm{OH}$ reaction).

The rate coefficient was combined with two different SOA-yields for the reaction, 0 or 22 mass $\%$, resulting in two different sensitivity test cases: 
(a) $k_{\mathrm{R} 4}=5.4 \times 10^{-13} \mathrm{~cm}^{3}$ molecule ${ }^{-1} \mathrm{~s}^{-1}, \alpha=0$

(b) $k_{\mathrm{R} 4}=5.4 \times 10^{-13} \mathrm{~cm}^{3}$ molecule ${ }^{-1} \mathrm{~s}^{-1}, \alpha=0.22$.

Canosa-Mas et al. (2002) suggest that photolysis may be the most important daytime loss process for MeSA but other studies have shown that MeSA and related compounds have "striking photostability" (e.g. Acuna et al., 1981) and therefore we neglect this process in the model simulations.

Deposition of gas-phase MeSA is a potentially important loss process since the oxidation rate is relatively slow. Karl et al. (2008) measured the Henry's law constant for MeSA and obtained a value of ca $34 \mathrm{Matm}^{-1}$; that is, MeSA is somewhat more soluble than $\mathrm{CH}_{3} \mathrm{CHO}$ but much less soluble than HCHO. In the standard set-up of the present study we treat MeSA-deposition in the same way as $\mathrm{CH}_{3} \mathrm{CHO}$ (and other higher aldehydes) in the EMEP model (Simpson et al., 2012); this means wet deposition is neglected and that the dry deposition is relatively slow. Two sensitivity tests were performed regarding the MeSA deposition: (A) neglecting both dry and wet deposition, and (B) assuming dry and wet deposition to be as efficient as for HCHO.

\subsection{Model emission scenarios}

In total, five different biotic stress emission scenarios are explored in this study and compared to a reference simulation without explicit stress-induced emissions. The different scenarios are based on the combination of the biotic stress emission factors described in Sect. 2.2 and the fractions of infected forest in Sect. 2.3; the resulting emission scenarios are summarized below and in Table 1. Note that in all scenarios except Case 3, the SIE are assumed to occur during the whole period with MT emissions (for central and northern Europe most of the MT emissions occur between March and October); i.e. biotic stress is assumed to be present during the whole growing season. This is a simplification, since many forms of biotic stress are of more limited duration (e.g. Hakola et al., 2006), but various stressors may be active at different times of the year. In the present study, the focus is on getting estimates of the potential relative importance of SIE compared to the constitutive BSOA for long-term OA concentrations.

\section{Case 0 - reference scenario}

Case 0 is a reference scenario excluding most stress-induced emissions. The biogenic emissions are the same as in the standard EMEP MSC-W model for carbonaceous aerosol (Bergström et al., 2012; Simpson et al., 2012) except that some SQT emissions were added (5\% of the MT emissions). The SOA-yield from SQT oxidation is set to 17 mass-\% (Mentel et al., 2013). The addition of $5 \%$ SQT is based on observations at the JPAC for experiments with no observable biotic stress. Since SQT emissions are mostly induced by biotic stress (Kleist et al., 2012; Mentel et al., 2013) the 5\%
SQT emissions used in Case 0 can be considered as covering a low "background" biotic stress situation.

\section{Case 1 - sesquiterpene emissions from biotic stress - current situation}

The first SIE scenario is based on experimental data for aphid-infested Norway spruce with a SQT/MT emission ratio of 2.4. In the EMEP model simulation for Case 1 we apply $10 \%$ of these emissions to all monoterpene emitting plants north of latitude $60^{\circ} \mathrm{N}$, during daytime, and $20 \%$ for $45-$ $60^{\circ} \mathrm{N}$. This means that the (daytime) SQT emissions are set to 24 and $48 \%$ of the MT emissions in the two different regions. The SOA yield from the SQT is the same as for Case $0(17 \%)$.

\section{Case 2 - methyl salicylate + sesquiterpene emissions from biotic stress - current situation}

The second scenario simulates an aphid-infested boreal forest, based on chamber data from experiments with a combination of Silver birch, Scots pine and Norway spruce. Chamber emission ratios were $\mathrm{SQT} / \mathrm{MT}=4.9$ and $\mathrm{MeSA} / \mathrm{MT}=3.5$. The assumption of $10 \%$ infested trees in the boreal forests (latitudes greater than $60^{\circ} \mathrm{N}$ ) and $20 \%$ for $45-60^{\circ} \mathrm{N}$ leads to model SQT/MT and MeSA/MT emissions of 49 and $35 \%$ for the northern region and 98 and $70 \%$ in the central region. For MeSA the SOA yield from oxidation by $\mathrm{OH}$ is $22 \%$ (Mentel et al., 2013); the standard Case 2 simulation assumes that MeSA only reacts with $\mathrm{OH}$, see Sect. 3.3 for sensitivity tests of different assumptions regarding the $\mathrm{MeSA}+\mathrm{NO}_{3}$ reactivity and SOA production.

\section{Case $1 \mathrm{~F}$ - increased degree of infestation - sesquiterpene emissions}

The first "future" scenario, Case 1F, uses the same biotic stress emission ratios as Case 1, but a larger proportion of the vegetation is assumed to be infested: $50 \%$ in the boreal region (north of $60^{\circ} \mathrm{N}$ ) and $2 / 3$ of the trees in the $45-60^{\circ} \mathrm{N}$ region. This leads to SQT/MT emission ratios of 120 and $160 \%$, respectively.

\section{Case 2F - increased degree of infestation - methyl salicylate + sesquiterpene emissions}

The second scenario of increased biotic stress, Case 2F, uses the same assumptions as Case 2 regarding the emissions from infested trees and the same proportion of infestation as in Case 1F. This leads to SQT/MT emission ratios of $245 \%$, in the northern region, and $327 \%$, in the central region. The corresponding MeSA/MT emission ratios were 175 and $233 \%$, respectively. 

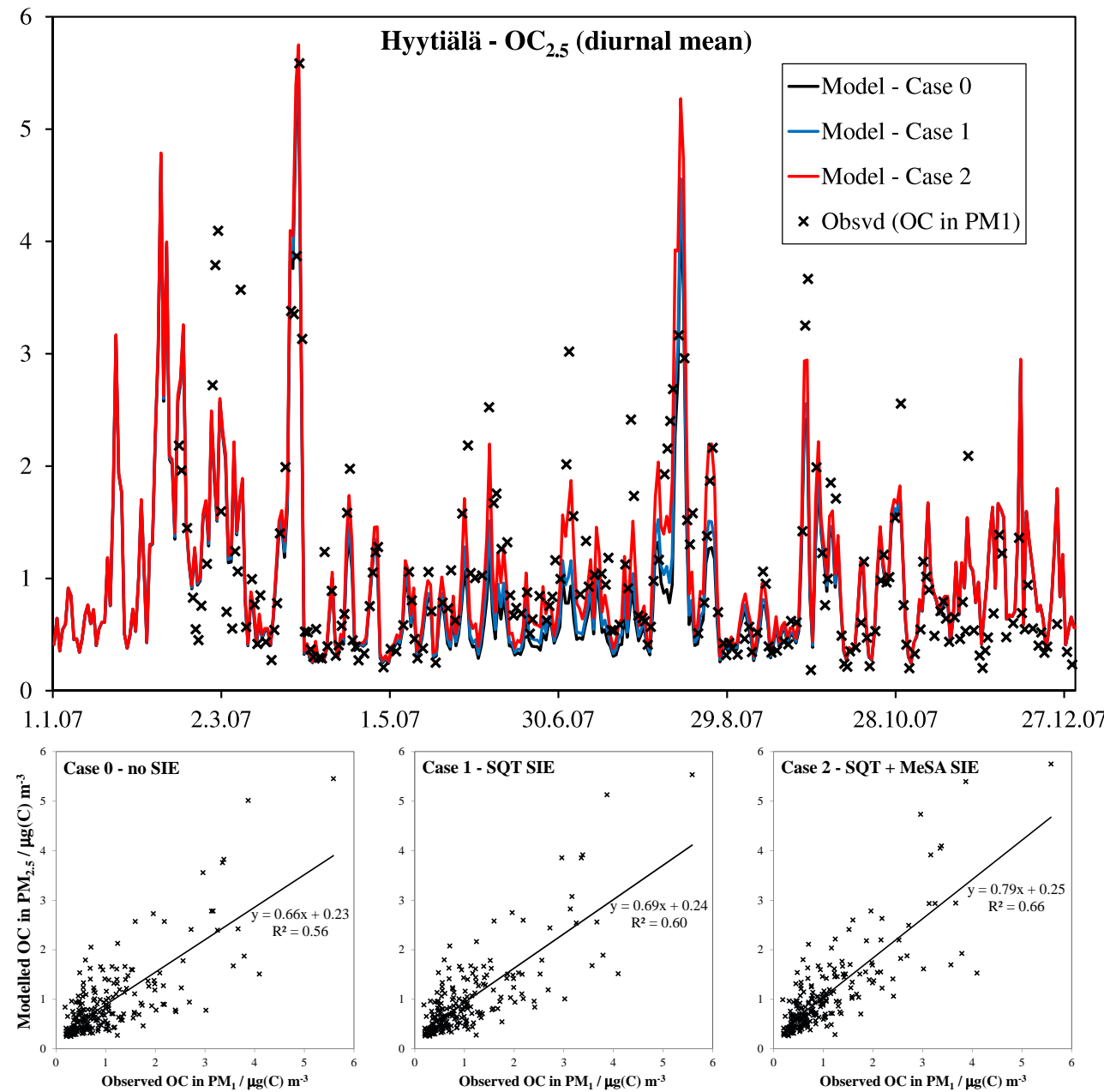

Figure 2. Modelled diurnal mean organic carbon in $\mathrm{PM}_{2.5}\left(\mathrm{OC}_{2.5}\right)$ at Hyytiälä (Finland) for 2007 compared to measured $\mathrm{OC}$ in $\mathrm{PM} 1$ (Aurela et al., 2011). Results from three different model simulations (see Sect. 2.5) are shown in the top panel: Case 0 (black line) - reference scenario, without explicit stress-induced emissions (SIE); Case 1 (blue) - current situation scenario with SIE of sesquiterpenes (SQT); Case 2 (red) current situation scenario with SIE of SQT and methyl salicylate. The lower panels show the model-measurement scatter plots for the three cases. Unit: $\mu \mathrm{g}(\mathrm{C}) \mathrm{m}^{-3}$.

\section{Case $3-\mathrm{C}_{17}$ BVOC + sesquiterpene emissions from regional episodic infestation by bark lice}

The Case 3 scenario, simulates an episodic infestation of Norway spruce by Cinara pilicornis in Baden-Württemberg (SE Germany, 47.8-49.8 $\mathrm{N}, 8.0-10.2^{\circ} \mathrm{E}$ ). The emission ratios, $\mathrm{C}_{17} \mathrm{BVOC} / \mathrm{MT}=18$ and $\mathrm{SQT} / \mathrm{MT}=1$, were applied to $38 \%$ of the BW forests during June and July, leading to large $\mathrm{C}_{17}$ BVOC emissions (6.8 $\times$ the MT emissions) and substantial SQT emissions $(0.38 \times \mathrm{MT})$ during this period. The SOA yield from the oxidation of $\mathrm{C}_{17} \mathrm{BVOC}$ is $33 \%$ (Mentel et al., 2013).

\section{Results and discussion}

The EMEP MSC-W model for OA was thoroughly evaluated against observations by Bergström et al. (2012). One of the conclusions of that study was that simple VBS based OA models can give reasonably good results for summer conditions. Since the biotic SIE primarily occur during the summer half-year, we focus here mainly on results for this period.

\subsection{Current situation}

Model calculated diurnal mean concentrations of organic carbon $\left(\mathrm{OC}_{2.5}\right)$ for the Finnish site Hyytiälä (located in a forest area in south-central Finland) are compared to measured OC (219 measurements in 2007 of OC in $\mathrm{PM}_{1}$ ) in Fig. 2. The model OC from all three "current-situation" scenarios (Case 0,1 and 2) are well correlated with the observations 


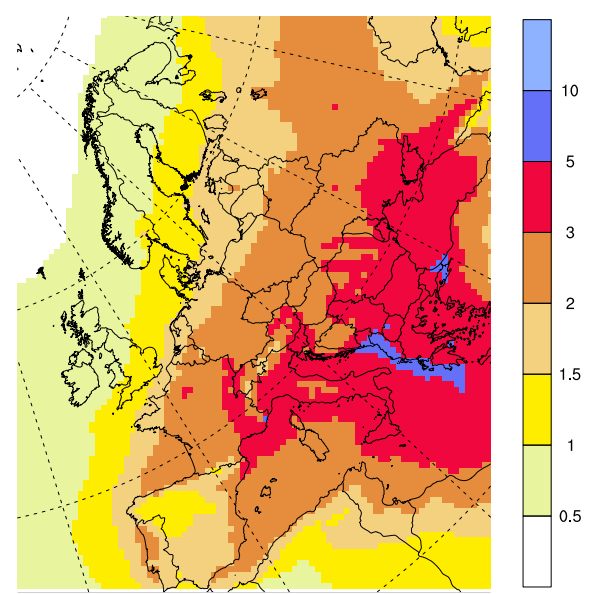

(a) Total $\mathrm{OM}_{2.5}$

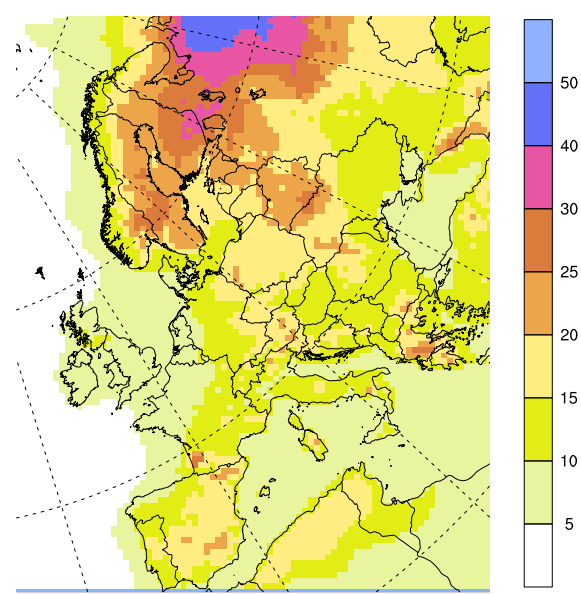

(b) BSOA-fraction (\%)

Figure 3. Model calculated 6-month mean (Apr-Sep) concentrations of (a) total Organic Matter in $\mathrm{PM}_{2.5}\left(\mathrm{OM}_{2.5}\right)\left(\mathrm{Unit} \mu \mathrm{gm}^{-3}\right)$. (b) Fraction of biogenic secondary organic aerosol (BSOA) (\% of total $\mathrm{OM}_{2.5}$ ) for the reference scenario without explicit biotic stress emissions (Case 0).

$\left(R^{2}\right.$-values are $0.56,0.60$ and 0.66 for Cases 0,1 and 2, respectively); the model-calculated concentrations are close to the observations, the average model bias is $-0.12,-0.08$ and $+0.03 \mu \mathrm{g} \mathrm{m}^{-3}$ (corresponding to $-12,-9$ and $+3 \%$ of the observed average); and the relative mean absolute deviation of the model $\mathrm{OC}_{2.5}$ from the observed $\mathrm{OC}_{1}$ are 39,36 and $33 \%$, respectively. The differences in performance between the three different model scenarios are not very large but Case 2 is slightly closer to observations than Case 1 and both SIE-scenarios are in better agreement with observations than the reference scenario (Case 0 ) that does not explicitly treat biotic stress emissions.

Since the model SIE are treated as a simple fraction of the "unstressed" MT emissions, an improvement in model results when adding SIE is not a proof that the stress-induced emissions are correctly modelled; the model improvement could also be due to compensation of underestimated regular BVOC emissions (see the example given for the Swiss site Payerne in Bergström et al., 2012). However, the model results for Hyytiälä shows that the additional SIE emissions do not lead to unrealistic model OA concentrations, and that such SIE can have a significant effect on ambient OA levels during the summer period.

Model calculated $\mathrm{OM}_{2.5}$ (organic matter in $\mathrm{PM}_{2.5}$ ) and the relative fraction of BSOA, from the reference case model simulation without explicit SIE from vegetation (Case 0), for the summer half-year (Apr-Sep) 2007, are shown in Fig. 3. The modelled BSOA is low in most of Europe. The relative contribution of BSOA to modelled regional background $\mathrm{OM}_{2.5}$ is below $20 \%$ except in parts of Northern Europe (parts of Sweden, Finland, the Baltic states, Russia, Belarus etc.) and some BVOC-emission hotspots. (The simulated absolute BSOA concentrations are below $0.6 \mu \mathrm{g} \mathrm{m}^{-3}$, except in the south-eastern Mediterranean region, parts of Russia, and some smaller high-BVOC-emission areas.)

The model calculated SIE-SOA for the two present-day biotic-stress emission scenarios (Case 1 and 2) are compared to the model BSOA from mostly unstressed plants (Case 0) in Fig. 4. Case 1-type SIE (only SQT-emissions) contribute somewhat less to BSOA than the (unstressed) constitutive BVOC emissions (SIE-SOA is below $0.3 \mu \mathrm{g} \mathrm{m}^{-3}$ in most of Europe, for the 6-month (Apr-Sep) mean and the SIESOA fraction of the total BSOA is between 20 and $40 \%$ in most of Europe north of lat. $45^{\circ} \mathrm{N}$ ). However, biotic SIE including MeSA (Case 2) give rise to high SIE-SOA in the model (between 0.6 and $1 \mu \mathrm{g} \mathrm{m}^{-3}$ in large parts of eastern and central Europe), clearly higher than the unstressed BSOAconcentration for the same period (between 50 and $80 \%$ of the total BSOA is SIE-SOA, for most of latitudes greater than $45^{\circ} \mathrm{N}$, in the Case 2 scenario). This shows that even with realistic present-day levels of biotic stress, it is possible that at least for some periods, the stress-induced emissions are more important for organic aerosol production than the constitutive emissions of BVOC.

\subsection{Future scenarios}

We have estimated the potential increase of $\mathrm{OM}_{2.5}$ due to the much higher degree of infestation assumed in the two future scenarios (Case $1 \mathrm{~F}$ and $2 \mathrm{~F}$ ). The differences in summer-halfyear mean $\mathrm{OM}_{2.5}$ between Case $1 \mathrm{~F}$ and Case 1 , and between Case 2F and Case 2 are shown in Fig. 5. If the biotic SIE increase to the high levels tested in these scenarios a substantial increase in organic particle mass can be expected. The results from the Case $2 \mathrm{~F}$ (biotic MeSA+SQT) simulation indicate that SIE-SOA could potentially become an important source of regional background $\mathrm{PM}_{2.5}$ in large parts of cen- 


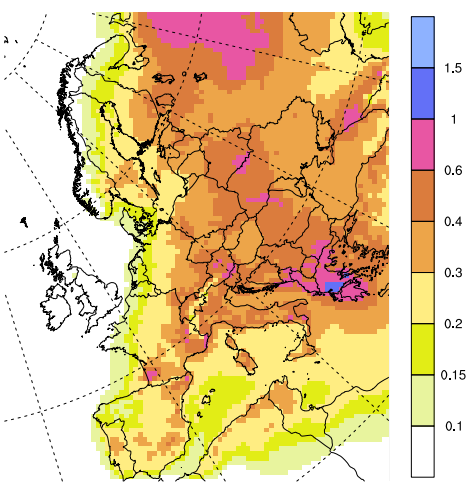

(a) Case 0 - BSOA

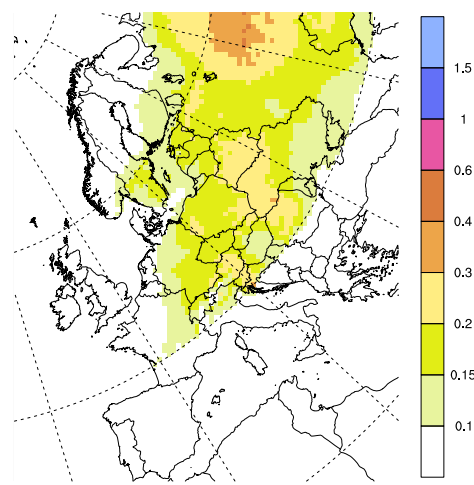

(b) Case 1 - SIE-OA

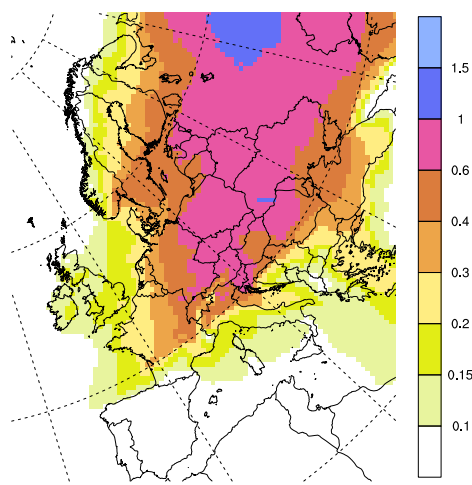

(c) Case 2 - SIE-OA

Figure 4. Model calculated 6-month mean (Apr-Sep) concentrations of BSOA and biotic stress-induced OA (SIE-OA); (a) BSOA in Case 0 (reference case without explicit stress-induced emissions), (b) SIE-OA in Case 1 (biotic stress with sesquiterpene (SQT) emissions), (c) SIE-OA in Case 2 (biotic stress with emissions of SQT and methyl salicylate). Unit: $\mu \mathrm{g} \mathrm{m}^{-3}$.

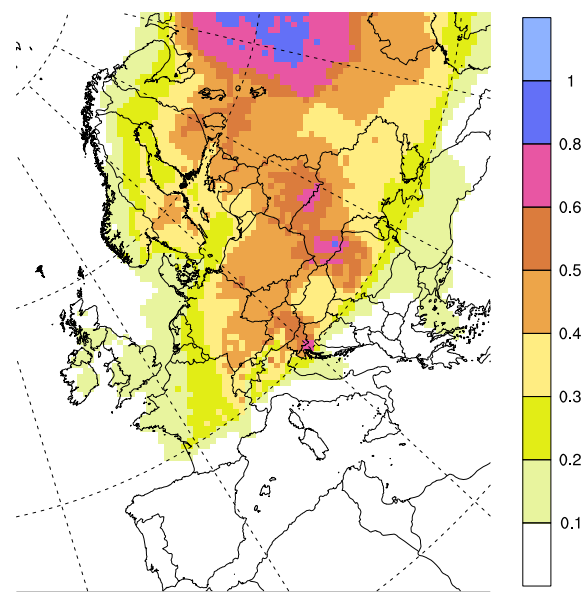

(a) Case $1 \mathrm{~F}-\mathrm{OM}_{2.5}$ increase

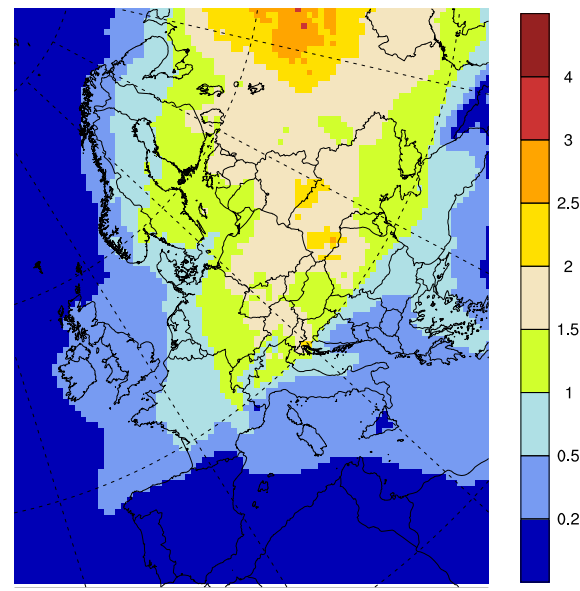

(b) Case $2 \mathrm{~F}-\mathrm{OM}_{2.5}$ increase

Figure 5. Potential increase of $\mathrm{OM}_{2.5}$ (6-month mean, Apr-Sep) from increased biotic stress-induced emissions (SIE) in two "maximum" impact scenarios, compared to the corresponding current-situation model calculated concentrations. The concentration-difference fields illustrate potential effects of a changed climate that the northern/central European forests have not had time to adapt to; (a) Difference in $\mathrm{OM}_{2.5}$ between Case $1 \mathrm{~F}$ and Case 1 (SIE with only SQT), (b) Case $2 \mathrm{~F}-$ Case 2 (SIE of both SQT and methyl salicylate). Unit: $\mu \mathrm{g} \mathrm{m}^{-3}$. Note: Different colour scales.

tral/eastern Europe; the increase in $\mathrm{OM}_{2.5}$ compared to the present-day Case 2-scenario is larger than $1.5 \mu \mathrm{g} \mathrm{m}^{-3}$ in parts of central and most of eastern Europe. The Case 1-type scenario, with only SIE of SQT included, have a much lower BSOA-forming potential but still the SIE-SOA production may become fairly substantial in the future scenario (Case $1 \mathrm{~F})$; the increase compared to the corresponding current situation scenario (Case 1) is above $0.3 \mu \mathrm{g} \mathrm{m}^{-3}$ in much of central, northern and eastern Europe.

\subsection{Importance of stress-induced MeSA emissions - sensitivity tests of MeSA chemistry and deposition}

Considering the high emissions of MeSA and high SOAyield from this component, further constraints on MeSA emissions and their impact on organic aerosol are important. MeSA is emitted by many different plant species, in response to various types of stress, not only the ones considered here (e.g. Vuorinen et al., 2007; Blande et al., 2010; Schnitzler et al., 2010). Assuming Case 2 SIE, model calculated MeSA concentrations in the gas-phase are relatively high; depending on the assumptions regarding MeSA-deposition and $\mathrm{NO}_{3}$-reactivity, the average MeSA concentrations for the period Mar-Oct at Hyytiälä are from 110 to $260 \mathrm{ppt}(\mathrm{v})$; see Fig. 6, which shows the diurnal variation of the modelled MeSA for four different model setups. If the model assumptions regarding the emissions and reactivity are realistic, MeSA should be easily detected in the atmosphere e.g. by PTR-MS or GC-MS. Our estimated MeSA concen- 


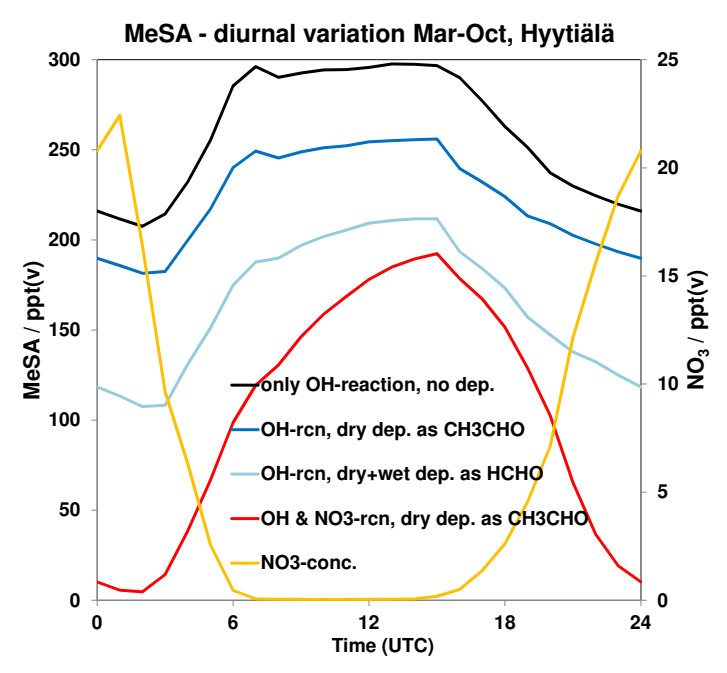

Figure 6. Modelled diurnal variation (average for the period MarOct) of methyl salicylate (MeSA) at Hyytiälä (Finland), using the Case 2 scenario for biotic stress-induced emissions. Comparison of model runs with four different assumptions regarding deposition losses and $\mathrm{NO}_{3}$-reactivity of MeSA. Black curve: only $\mathrm{OH}$ reaction, no deposition of MeSA; dark blue: $\mathrm{OH}$ reaction, dry deposition of MeSA with the same deposition velocity as acetaldehyde; light blue: $\mathrm{OH}$ reaction, wet and dry deposition of MeSA with the same treatment as formaldehyde; red: $\mathrm{NO}_{3}$ reaction $(k=$ $5.4 \times 10^{-13} \mathrm{~cm}^{3}$ molecule $\left.{ }^{-1} \mathrm{~s}^{-1}\right), \mathrm{OH}$ reaction, dry depostion as acetaldehyde. The modelled concentration of $\mathrm{NO}_{3}$ is also shown (orange curve, right axis). Unit: ppt(v).

trations are of the same order of magnitude as observed by Karl et al. (2008). They found MeSA mixing ratios of $\sim 100 \mathrm{ppt}(\mathrm{v})$ within and above the canopy of a walnut agroforest.

The amount of SIE-SOA produced in the model in Case 2 is based on the observed SOA formation in the JPAC plantchamber experiments (Mentel et al., 2013); in addition it depends on the assumptions regarding the deposition of MeSA, the $\mathrm{MeSA}+\mathrm{NO}_{3}$ reactivity and the SOA-formation from the $\mathrm{NO}_{3}$ reaction. We illustrate the sensitivities in Fig. 7, which shows the mean diurnal variation of SIE-SOA at Hyytiälä for the period Mar-Oct.

The modelled SIE-SOA is not very sensitive to the MeSA deposition; the differences between the setups with no deposition or faster deposition (as HCHO) to the base case deposition (as $\mathrm{CH}_{3} \mathrm{CHO}$ ) are only about +5 and $-7 \%$, respectively; similar differences $(+3-+7 \%$ and $-3--10 \%)$ are seen in the part of the model domain where the SIE are included in Case 2 (the relative differences are larger at longer distances from the SIE regions).

If the MeSA $+\mathrm{NO}_{3}$ reaction occurs at the rate tested in this study, $\left(k_{\mathrm{R} 4}=5.4 \times 10^{-13} \mathrm{~cm}^{3}\right.$ molecule $\left.\mathrm{e}^{-1} \mathrm{~s}^{-1}\right)$, and has the same SOA-yield as MeSA+OH, a substantial nighttime production of SIE-SOA is seen in the model. The average modelled (total) SIE-SOA concentration at Hyytiälä is about

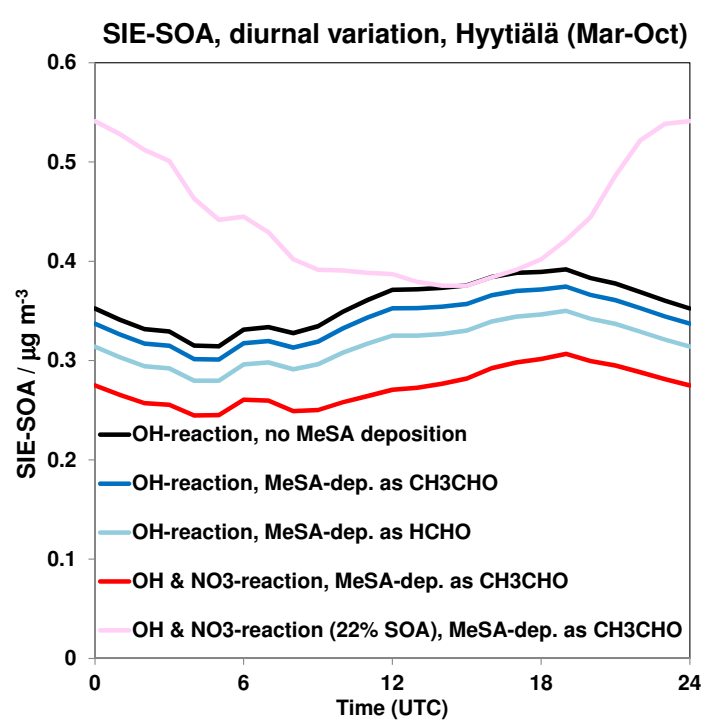

Figure 7. Modelled diurnal variation (average for the period MarOct) of SIE-SOA at Hyytiälä using the Case 2 scenario for biotic stress-induced emissions, with different assumptions regarding MeSA deposition losses, $\mathrm{NO}_{3}$-reactivity and SOA-yield. Black curve: only $\mathrm{OH}$ reaction, no deposition of MeSA; dark blue: $\mathrm{OH}$ reaction, dry deposition of MeSA with the same deposition velocity as acetaldehyde; light blue: $\mathrm{OH}$ reaction, wet and dry deposition of MeSA with the same treatment as formaldehyde; red: $\mathrm{OH}$ reaction, $\mathrm{NO}_{3}$ reaction $\left(k=5.4 \times 10^{-13} \mathrm{~cm}^{3}\right.$ molecule $\left.{ }^{-1} \mathrm{~s}^{-1}\right)$, no SOA from $\mathrm{MeSA}+\mathrm{NO}_{3}$ reaction, dry depostion as acetaldehyde; pink: $\mathrm{OH}$ reaction, $\mathrm{NO}_{3}$ reaction with $22 \%$ SOA-yield, dry depostion as acetaldehyde. Unit: $\mu \mathrm{g} \mathrm{m}^{-3}$.

$30 \%$ higher when the $\mathrm{NO}_{3}$ reaction is included than for the case with only the $\mathrm{OH}$ reaction (results are similar in most of Europe north of lat. $45^{\circ} \mathrm{N}$, for Apr-Sep: typically $+20-$ $+30 \%$ ). If the MeSA $+\mathrm{NO}_{3}$ reaction consumes the MeSA without SOA-production, the SIE-SOA formation is reduced compared to the case with only $\mathrm{OH}$ reaction; at Hyytiälä modelled SIE-SOA is about $20 \%$ lower than for the case that neglects the $\mathrm{MeSA}+\mathrm{NO}_{3}$ reaction (similarly, for most of the region with significant SIE in Case 2, the modelled SIE-SOA is reduced by ca. $15-25 \%$, compared to the base case with only $\mathrm{OH}$ reaction included).

The standard Case 2 simulation (as used in Sect. 3.1), which neglects the MeSA $+\mathrm{NO}_{3}$ reaction, leads to SIE-SOA concentrations between those obtained in the two test case simulations that include the $\mathrm{MeSA}+\mathrm{NO}_{3}$ reaction (with 0 and $22 \%$ SOA yield); the average SIE-SOA (for Mar-Oct)

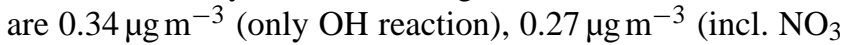
reaction with $0 \%$ SOA-yield) and $0.44 \mu \mathrm{g} \mathrm{m}^{-3}$ (incl. $\mathrm{NO}_{3}$ reaction, $22 \%$ SOA-yield). Neglecting the $\mathrm{NO}_{3}$ reaction means that more MeSA survive during nighttime and can produce SIE-SOA the following day via $\mathrm{OH}$ reaction. As seen in Fig. 6 almost all MeSA is lost during night when the $\mathrm{NO}_{3}$ reaction is taken into account. 


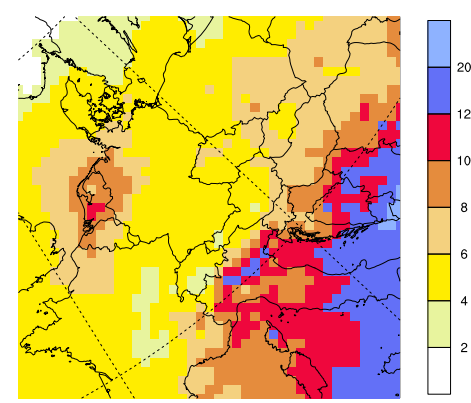

(a) Case 0 - $\mathrm{PM}_{2.5}$

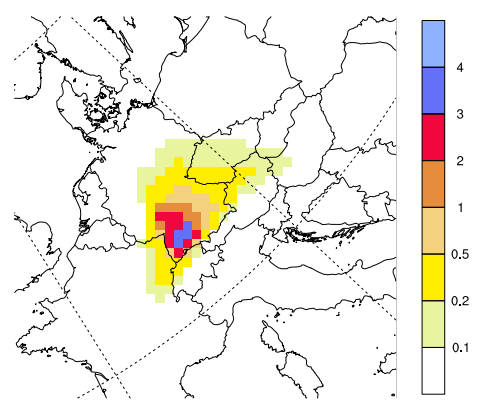

(b) Case3 - add. $\mathrm{PM}_{2.5}$

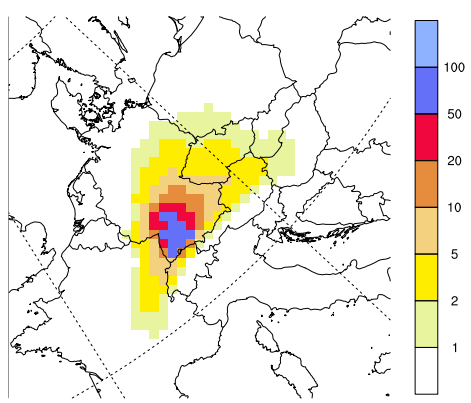

(c) Rel. increase $\mathrm{PM}_{2.5}(\%)$

Figure 8. Model calculated regional background $\mathrm{PM}_{2.5}$ concentration (2-month-mean for Jun-Jul). (a) Total model $\mathrm{PM}_{2.5}$ without explicit biotic stress emissions (Case 0$)\left(\mu \mathrm{g} \mathrm{m}^{-3}\right)$; (b) Additional $\mathrm{PM}_{2.5}$ due to organic aerosol formation caused by biotic stress-induced emissions in Case 3 (infestation of Spruce in Baden-Württemberg by Cinara pilicornis) $\left(\mu \mathrm{g} \mathrm{m}^{-3}\right.$ ); (c) Relative increase in modelled regional background $\mathrm{PM}_{2.5}$ (in \%) due to the simulated infestation.

The model calculated $\mathrm{NO}_{3}$ concentrations are very high compared to the sub-ppt levels reported by Rinne et al. (2012) at canopy height in Hyytiälä. However, aloft levels of $\mathrm{NO}_{3}$ are often observed or calculated to be far higher than ground-level data (Brown and Stutz, 2012; Johansson and Janson, 1993), so our values may be reasonable. In any case, model calculations where we relax our oxidant-neutrality assumption (Sect. 2.4) and allow $100 \%$ loss of $\mathrm{NO}_{3}$ have shown that even though $\mathrm{NO}_{3}$ levels are reduced dramatically, the effect on SIE-SOA is moderate, about $30 \%$.

The SOA formation from the $\mathrm{NO}_{3}$ reaction is difficult to assess, but if the ambient MeSA levels are indeed often at a level higher than $100 \mathrm{ppt}$ it is worthwhile to study the MeSA $-\mathrm{NO}_{3}$ yield in more detail. Moreover, recent data indicate very efficient $\mathrm{SOA}$ formation from $\mathrm{NO}_{3}$ reactions of e.g. pool emitted MT (Fry et al., 2009, 2011).

\subsection{Regional bark lice infestation - Case 3}

The very large episodic $\mathrm{C}_{17}$-BVOC emissions in BadenWürttemberg, simulated in Case 3, lead to a large production of SIE-SOA in the infested region. For the 2-month infestation period, the average modelled SIE-SOA contribution to $\mathrm{PM}_{2.5}$ is larger than $3 \mu \mathrm{g} \mathrm{m}^{-3}$ in $\mathrm{BW}$ and above $0.5 \mu \mathrm{g} \mathrm{m}^{-3}$ in all of southern Germany. For BW, the modelled regional background $\mathrm{PM}_{2.5}$ concentration is more than twice that in the reference case without SIE, as shown in Fig. 8. Since Case 3 assumes a wide-spread, severe infestation of spruce trees in BW, it could be considered a "worstcase" scenario for lice infestation in BW (or best-case for the honey-production) but it should be pointed out that bark lice may infect other tree species as well and that infestations are likely to occur simultaneously in other regions of Europe. The very high modelled impact of this scenario also indicates that even a much more limited degree of infestation could lead to substantially enhanced OA concentrations. The emissions of $\mathrm{C}_{17}$ BVOC from insect-infested vegetation is thus a field worth further investigation.

\section{Conclusions}

A large number of different biotic stressors exist in the environment and many plants are obviously infested by at least some stress-inducing organisms as shown in ICP Forests, 2011 (chap. 2, Figs. 2-4 and 2-5). The inspections of European forests suggest that totally non-infested plants are not likely to be common and thus some stress is the normal state of vegetation. New laboratory data indicate that stressinduced emissions (SIE) from trees common in central and northern Europe may be of great importance for SOA formation under current conditions. SIE are difficult to assess but the emission factors for the different SIE compounds included in this study (sesquiterpenes, SQT; methyl salicylate, MeSA; unsaturated linear $\mathrm{C}_{17} \mathrm{BVOC}$ ) have been inferred from plant chamber SOA experiments.

In this study we estimated the degree of stress from forest damage observations in Europe and forest-honey production data from beekeepers in south-west Germany. Combining these estimates with the plant-chamber-experimentbased stress-induced emission factors, we constructed different SIE scenarios, and implemented SIE-SOA formation in the EMEP MSC-W model in order to get a first model estimate of the potential impact of SIE in Europe north of lat. $45^{\circ} \mathrm{N}$.

The implementation of SIE in the model resulted in less bias and better correlation coefficients, for particulate organic carbon at a forest site in Finland, compared to the standard model simulation with only constitutive biogenic emissions. However, based on these results alone, we cannot draw the conclusion that this is proof of the importance of SIE, since any increase in BVOC emissions, or BSOA yields from unstressed BVOC, would have essentially identical effects on total organic aerosol concentrations: we cannot distinguish SIE induced SOA from SOA from unstressed vegetation with higher emission rates. On the other hand we also cannot distinguish between much higher abundance of SIE- 
SOA already at present and overestimated SOA from constitutive emissions. Furthermore, the fate of the SIE in the atmosphere is uncertain, as shown by the sensitivity tests of the MeSA chemistry and deposition, and the modelling of SOA is still so fraught with difficulty that we cannot use modelmeasurement discrepancy for total OA concentrations to establish the likely level of SIE-SOA.

Having stated this, we want to point out that if our assumptions regarding the magnitude of the SIE are overall about right, it is possible that, at least for some periods, the SIE including MeSA could be more important for organic aerosol production than the constitutive emissions of BVOC. SIE of SQT have a lower BSOA-forming potential but still the SIE-SOA production from SQT may become fairly substantial in the future in much of central, northern and eastern Europe. The emissions of unsaturated $\mathrm{C}_{17}$ BVOC from insect-infested vegetation, although episodic and regional, could have a large impact on SOA formation. If the climate changes relatively rapidly (on the time scale of the life span of individual trees), established vegetation may have problems adapting to the new conditions, which could make the trees more vulnerable to different stressors; this can lead to increased SIE in the future.

Measurements using real plant emissions have shown that SIE can have higher potential to form SOA mass than constitutive emissions. On the laboratory scale, SIE can dominate SOA formation, as is also reflected by the model calculations. But up-scaling of laboratory results is complicated because the contribution of SIE to biogenic emissions in the air over large areas is uncertain. We constructed plausible scenarios, for central and northern Europe, by using independent data on European forest systems. This approach is only a first step and may lead to over or underestimations of the importance of SIE-SOA. However, without consideration of SIESOA, modelling scenarios will remain unrealistic. A limitation of the present study is that the stress-induced emissions and SIE-SOA yields are based on data for a limited number of tree species and stressors (Mentel et al., 2013).

The uncertainties encountered in our approach point to the need to quantify SIE directly in the field. The agreement of the model-predicted MeSA level with observations by Karl et al. (2008) encourage such initiatives. Our findings suggest that the SIE and SIE-SOA are potentially important, at least in large parts of Europe, and that there is need for additional efforts in further investigations.

Acknowledgements. This work was funded by the Swedish Clean Air Research Programme (SCARP), EU projects ECLAIRE (project no: 282910), PEGASOS (no: 265148), as well as EMEP under UNECE. The work is also a contribution to the Swedish Climate Modelling project MERGE and the Climate change and Environmental Objectives (CLEO) research programme.

We would like to thank ICP Forests and the beekeepers of BadenWürttemberg for helpful comments and for allowing the use of material from their reports and webpages.
Thanks also to Sanna Saarikoski for providing the observational OC data from Hyytiälä.

Edited by: E. Nemitz

\section{References}

Aas, W., Tsyro, S., Bieber, E., Bergström, R., Ceburnis, D., Ellermann, T., Fagerli, H., Frölich, M., Gehrig, R., Makkonen, U., Nemitz, E., Otjes, R., Perez, N., Perrino, C., Prévôt, A. S. H., Putaud, J.-P., Simpson, D., Spindler, G., Vana, M., and Yttri, K. E.: Lessons learnt from the first EMEP intensive measurement periods, Atmos. Chem. Phys., 12, 8073-8094, doi:10.5194/acp12-8073-2012, 2012.

Acuna, A. U., Catalan, J., and Toribio, F.: Photon Energy Relaxation and Thermal Effects on Gas-Phase Electronically Excited Methyl Salicylate, J. Phys. Chem., 85, 241-245, 1981.

Ahlström, A., Schurgers, G., Arneth, A., and Smith, B.: Robustness and uncertainty in terrestrial ecosystem carbon response to CMIP5 climate change projections, Environ. Res. Lett., 7, doi:10.1088/1748-9326/7/4/044008, 2012.

Aksoyoglu, S., Keller, J., Barmpadimos, I., Oderbolz, D., Lanz, V. A., Prévôt, A. S. H., and Baltensperger, U.: Aerosol modelling in Europe with a focus on Switzerland during summer and winter episodes, Atmos. Chem. Phys., 11, 7355-7373, doi:10.5194/acp11-7355-2011, 2011.

Allan, J. D., Alfarra, M. R., Bower, K. N., Coe, H., Jayne, J. T., Worsnop, D. R., Aalto, P. P., Kulmala, M., Hyötyläinen, T., Cavalli, F., and Laaksonen, A.: Size and composition measurements of background aerosol and new particle growth in a Finnish forest during QUEST 2 using an Aerodyne Aerosol Mass Spectrometer, Atmos. Chem. Phys., 6, 315-327, doi:10.5194/acp-6-315-2006, 2006.

Amin, H., Atkins, P. T., Russo, R. S., Brown, A. W., Sive, B., Hallar, A. G., and Hartz, K. E. H.: Effect of Bark Beetle Infestation on Secondary Organic Aerosol Precursor Emissions, Environ. Sci. Technol., 46, 5696-5703, doi:10.1021/es204205m, 2012.

Amin, H. S., Russo, R. S., Sive, B., Hoebeke, E. R., Dodson, C., McCubbin, I. B., Hallar, A. G., and Hartz, K. E. H.: Monoterpene emissions from bark beetle infested Engelmann spruce trees, Atmos. Environ., 72, 130-133, doi:10.1016/j.atmosenv.2013.02.025, 2013.

Andersson-Sköld, Y. and Simpson, D.: Comparison of the chemical schemes of the EMEP MSC-W and the IVL photochemical trajectory models, Atmos. Environ., 33, 1111-1129, 1999.

Andersson-Sköld, Y. and Simpson, D.: Secondary organic aerosol formation in Northern Europe: a model study, J. Geophys. Res., 106, 7357-7374, 2001.

Arneth, A. and Niinemets, U.: Induced BVOCs: how to bug our models?, Trends in Plant Science, 15, 118-125, doi:10.1016/j.tplants.2009.12.004, 2010.

Arneth, A., Harrison, S. P., Zaehle, S., Tsigaridis, K., Menon, S., Bartlein, P. J., Feichter, J., Korhola, A., Kulmala, M., O'Donnell, D., Schurgers, G., Sorvari, S., and Vesala, T.: Terrestrial biogeochemical feedbacks in the climate system, Nature Geoscience, 3 , 525-532, doi:10.1038/ngeo905, 2010. 
Arneth, A., Schurgers, G., Lathiere, J., Duhl, T., Beerling, D. J., Hewitt, C. N., Martin, M., and Guenther, A.: Global terrestrial isoprene emission models: sensitivity to variability in climate and vegetation, Atmos. Chem. Phys., 11, 8037-8052, doi:10.5194/acp-11-8037-2011, 2011.

Aurela, M., Saarikoski, S., Timonen, H., Aalto, P., Keronen, P., Saarnio, K., Teinilä, K., Kulmala, M., and Hillamo, R.: Carbonaceous aerosol at a forested and an urban background sites in Southern Finland, Atmos. Environ., 45, 1394-1401, doi:10.1016/j.atmosenv.2010.12.039, 2011.

Beddows, D. C. S., Dall'Osto, M., Harrison, R. M., Kulmala, M., Asmi, A., Wiedensohler, A., Laj, P., Fjaeraa, A., Sellegri, K., Birmili, W., Bukowiecki, N., Weingartner, E., Baltensperger, U., Zdimal, V., Zikova, N., Putaud, J.-P., Marinoni, A., Tunved, P., Hansson, H.-C., Fiebig, M., Kivekäs, N., Swietlicki, E., Lihavainen, H., Asmi, E., Ulevicius, V., Aalto, P. P., Mihalopoulos, N., Kalivitis, N., Kalapov, I., Kiss, G., de Leeuw, G., Henzing, B., O’Dowd, C., Jennings, S. G., Flentje, H., Meinhardt, F., Ries, L., Denier van der Gon, H. A. C., and Visschedijk, A. J. H.: Variations in tropospheric submicron particle size distributions across the European continent 2008-2009, Atmos. Chem. Phys., 14, 4327-4348, doi:10.5194/acp-14-4327-2014, http://www.atmos-chem-phys.net/14/4327/2014/, 2014.

Berg, A. R., Heald, C. L., Hartz, K. E. H., Hallar, A. G., Meddens, A. J. H., Hicke, J. A., Lamarque, J. F., and Tilmes, S.: The impact of bark beetle infestations on monoterpene emissions and secondary organic aerosol formation in western North America, Atmos. Chem. Phys., 13, 3149-3161, doi:10.5194/acp-13-31492013, 2013.

Berge, E. and Jakobsen, H. A.: A regional scale multi-layer model for the calculation of long-term transport and deposition of air pollution in Europe, Tellus, 50, 205-223, 1998.

Bergström, R., Denier van der Gon, H. A. C., Prévôt, A. S. H., Yttri, K. E., and Simpson, D.: Modelling of organic aerosols over Europe (2002-2007) using a volatility basis set (VBS) framework: application of different assumptions regarding the formation of secondary organic aerosol, Atmos. Chem. Phys., 12, 8499-8527, doi:10.5194/acp-12-8499-2012, 2012.

Blande, J. D., Korjus, M., and Holopainen, J. K.: Foliar methyl salicylate emissions indicate prolonged aphid infestation on silver birch and black alder, Tree Physiol., 30, 404-416, 2010.

Bonn, B. and Moortgat, G.: Sesquiterpene ozonolysis: Origin of atmospheric new particle formation from biogenic hydrocarbons, Geophys. Res. Lett., 30, doi:10.1029/2003GL017000, 2003.

Bowman, F., Odum, J., Seinfeld, J., and Pandis, S.: Mathematical Modelling for Gas-Particle Partitioning of Secondary Organic Aerosols, Atmos. Environ., 31, 3921-3931, 1997.

Brown, S. S. and Stutz, J.: Nighttime radical observations and chemistry, Chem. Soc. Rev., 41, 6405-6447, doi:10.1039/c2cs35181a, 2012.

Canosa-Mas, C., Duffy, J., King, M., Thompson, K., and Wayne, R.: The atmospheric chemistry of methyl salicylate - reactions with atomic chlorine and with ozone, Atmos. Environ., 36, 22012205, doi:10.1016/S1352-2310(02)00173-5, 2002.

Denier van der Gon, H. A. C., Bergström, R., Fountoukis, C., Johansson, C., Pandis, S., Simpson, D., and Visschedijk, A.: Particulate emissions from residential wood combustion in Europe - revised estimates and an evaluation, Atmos. Chem. Phys.
Discuss., 14, 31719-31765, doi:10.5194/acpd-14-31719-2014, 2014.

Donahue, N., Robinson, A., Stanier, C., and Pandis, S.: Coupled Partitioning, Dilution, and Chemical Aging of Semivolatile Organics, Environ. Sci. Technol., 40, 2635-2643, doi:10.1021/es052297c, 2006.

Donahue, N. M., Robinson, A. L., and Pandis, S. N.: Atmospheric organic particulate matter: From smoke to secondary organic aerosol, Atmos. Environ., 43, 94-106, doi:10.1016/j.atmosenv.2008.09.055, atmospheric Environment - Fifty Years of Endeavour, 2009.

Donahue, N. M., Henry, K. M., Mentel, T. F., Kiendler-Scharr, A., Spindler, C., Bohn, B., Brauers, T., Dorn, H. P., Fuchs, H., Tillmann, R., Wahner, A., Saathoff, H., Naumann, K.-H., Moehler, O., Leisner, T., Mueller, L., Reinnig, M.-C., Hoffmann, T., Salo, K., Hallquist, M., Frosch, M., Bilde, M., Tritscher, T., Barmet, P., Praplan, A. P., DeCarlo, P. F., Dommen, J., Prevot, A. S. H., and Baltensperger, U.: Aging of biogenic secondary organic aerosol via gas-phase $\mathrm{OH}$ radical reactions, P. Natl. Acad. Sci. USA, 109, 13503-13508, doi:10.1073/pnas.1115186109, 2012.

Duhl, T. R., Helmig, D., and Guenther, A.: Sesquiterpene emissions from vegetation: a review, Biogeosciences, 5, 761-777, doi:10.5194/bg-5-761-2008, 2008.

Ehn, M., Kleist, E., Junninen, H., Petäjä, T., Lönn, G., Schobesberger, S., Dal Maso, M., Trimborn, A., Kulmala, M., Worsnop, D. R., Wahner, A., Wildt, J., and Mentel, T. F.: Gas phase formation of extremely oxidized pinene reaction products in chamber and ambient air, Atmos. Chem. Phys., 12, 5113-5127, doi:10.5194/acp-12-5113-2012, 2012.

Fagerli, H. and Aas, W.: Trends of nitrogen in air and precipitation: Model results and observations at EMEP sites in Europe, 19802003, Environ. Poll., 154, 448-461, 2008.

Ferretti, M., Fischer, R., Mues, V., Granke, O., and Lorenz, M.: Basic design principles for the ICP Forests Monitoring Networks. Manual Part II, in: Manual on methods and criteria for harmonized sampling, assessment, monitoring and analysis of the effects of air pollution on forests., p. 22 pp., UNECE ICP Forests Programme Co-ordinating Centre, Hamburg, 2010.

Fischer, R., Waldner, P., Carnicer, J., Coll, M., Dobbertin, M., Ferretti, M., Hansen, K., Kindermann, G., Lasch-Born, P., Lorenz, M., Marchetto, A., Meining, S., Nieminen, T., Peñuelas, J., Rautio, P., Reyer, C., Roskams, P., and Sánchez, G.: The Condition of Forests in Europe. 2012 Executive Report, ICP Forests Report ISSN 1020-587X, ICP Forests, Hamburg, http://www. icp-forests.org/RepEx.htm, 2012.

Fountoukis, C., Racherla, P. N., Denier van der Gon, H. A. C., Polymeneas, P., Charalampidis, P. E., Pilinis, C., Wiedensohler, A., Dall'Osto, M., O'Dowd, C., and Pandis, S. N.: Evaluation of a three-dimensional chemical transport model (PMCAMx) in the European domain during the EUCAARI May 2008 campaign, Atmos. Chem. Phys., 11, 10331-10347, doi:10.5194/acp11-10331-2011, 2011.

Fry, J. L., Kiendler-Scharr, A., Rollins, A. W., Wooldridge, P. J., Brown, S. S., Fuchs, H., Dubé, W., Mensah, A., dal Maso, M., Tillmann, R., Dorn, H.-P., Brauers, T., and Cohen, R. C.: Organic nitrate and secondary organic aerosol yield from $\mathrm{NO}_{3}$ oxidation of $\beta$-pinene evaluated using a gas-phase kinetics/aerosol partitioning model, Atmos. Chem. Phys., 9, 14311449, doi:10.5194/acp-9-1431-2009, 2009. 
Fry, J. L., Kiendler-Scharr, A., Rollins, A. W., Brauers, T., Brown, S. S., Dorn, H.-P., Dubé, W. P., Fuchs, H., Mensah, A., Rohrer, F., Tillmann, R., Wahner, A., Wooldridge, P. J., and Cohen, R. C.: SOA from limonene: role of $\mathrm{NO}_{3}$ in its generation and degradation, Atmos. Chem. Phys., 11, 3879-3894, doi:10.5194/acp-113879-2011, 2011.

Gauss, M., Tsyro, S., Steensen, B. M., and Hjellbrekke, A.-G.: EMEP/MSC-W model performance for acidifying and eutrophying components, photo-oxidants and particulate matter in 2012., Supplementary material to EMEP status report 1/2014, The Norwegian Meteorological Institute, Oslo, Norway, www.emep.int, 2014.

Gelencsér, A., May, B., Simpson, D., Sánchez-Ochoa, A., KasperGiebl, A., Puxbaum, H., Caseiro, A., Pio, C., and Legrand, M.: Source apportionment of $\mathrm{PM}_{2.5}$ organic aerosol over Europe: primary/secondary, natural/anthropogenic, fossil/biogenic origin, J. Geophys. Res., 112, D23S04, doi:10.1029/2006JD008094, 2007.

Genberg, J., Denier van der Gon, H. A. C., Simpson, D., Swietlicki, E., Areskoug, H., Beddows, D., Ceburnis, D., Fiebig, M., Hansson, H. C., Harrison, R. M., Jennings, S. G., Saarikoski, S., Spindler, G., Visschedijk, A. J. H., Wiedensohler, A., Yttri, K. E., and Bergström, R.: Light-absorbing carbon in Europe - measurement and modelling, with a focus on residential wood combustion emissions, Atmos. Chem. Phys., 13, 87198738, doi:10.5194/acp-13-8719-2013, 2013.

Guenther, A., Karl, T., Harley, P., Wiedinmyer, C., Palmer, P. I., and Geron, C.: Estimates of global terrestrial isoprene emissions using MEGAN (Model of Emissions of Gases and Aerosols from Nature), Atmos. Chem. Phys., 6, 3181-3210, 2006, http://www.atmos-chem-phys.net/6/3181/2006/.

Guenther, A. B., Jiang, X., Heald, C. L., Sakulyanontvittaya, T., Duhl, T., Emmons, L. K., and Wang, X.: The Model of Emissions of Gases and Aerosols from Nature version 2.1 (MEGAN2.1): an extended and updated framework for modeling biogenic emissions, Geoscientific Model Dev., 5, 1471-1492, doi:10.5194/gmd-5-1471-2012, 2012.

Haase, K. B., Jordan, C., Mentis, E., Cottrell, L., Mayne, H. R., Talbot, R., and Sive, B. C.: Changes in monoterpene mixing ratios during summer storms in rural New Hampshire (USA), Atmos. Chem. Phys., 11, 11465-11476, doi:10.5194/acp-1111465-2011, 2011.

Hakola, H., Tarvainen, V., Bäck, J., Ranta, H., Bonn, B., Rinne, J., and Kulmala, M.: Seasonal variation of mono- and sesquiterpene emission rates of Scots pine, Biogeosciences, 3, 93-101, doi:10.5194/bg-3-93-2006, 2006.

Hallquist, M., Wenger, J. C., Baltensperger, U., Rudich, Y., Simpson, D., Claeys, M., Dommen, J., Donahue, N. M., George, C., Goldstein, A. H., Hamilton, J. F., Herrmann, H., Hoffmann, T., Iinuma, Y., Jang, M., Jenkin, M. E., Jimenez, J. L., Kiendler-Scharr, A., Maenhaut, W., McFiggans, G., Mentel, Th. F., Monod, A., Prévôt, A. S. H., Seinfeld, J. H., Surratt, J. D., Szmigielski, R., and Wildt, J.: The formation, properties and impact of secondary organic aerosol: current and emerging issues, Atmos. Chem. Phys., 9, 5155-5236, doi:10.5194/acp-9-51552009, 2009.

Heald, C. L., Jacob, D. J., Park, R. J., Russell, L. M., Huebert, B. J., Seinfeld, J. H., Liao, H., and Weber, R. J.: A large organic aerosol source in the free troposphere missing from current models, Geophys. Res. Lett., 32, L18809, doi:10.1029/2005GL023831 2005.
Holopainen, J.: Can forest trees compensate stress-generated growth losses by induced production of volatile compounds?, Tree Physiology, 31, 1356-1377, 2011.

ICP Forests: The Condition of Forests in Europe. 2011 Executive Report, ICP Forests Report ISSN 1020-587X, ICP Forests, Hamburg, http://www.icp-forests.org/RepEx.htm, 2011.

Jaoui, M., Kleindienst, T. E., Docherty, K. S., Lewandowski, M., and Offenberg, J. H.: Secondary organic aerosol formation from the oxidation of a series of sesquiterpenes: alpha-cedrene, beta-caryophyllene, alpha-humulene and alpha-farnesene with $\mathrm{O}_{3}, \mathrm{OH}$ and $\mathrm{NO}_{3}$ radicals, Environ. Chem., 10, 178-193, doi:10.1071/EN13025, 2013.

Jenkin, M. E., Wyche, K. P., Evans, C. J., Carr, T., Monks, P. S., Alfarra, M. R., Barley, M. H., McFiggans, G. B., Young, J. C., and Rickard, A. R.: Development and chamber evaluation of the MCM v3.2 degradation scheme for $\beta$-caryophyllene, Atmos. Chem. Phys., 12, 5275-5308, doi:10.5194/acp-12-52752012, 2012.

Jimenez, J. L., Canagaratna, M. R., Donahue, N. M., Prevot, A. S. H., Zhang, Q., Kroll, J. H., DeCarlo, P. F., Allan, J. D., Coe, H., Ng, N. L., Aiken, A. C., Docherty, K. S., Ulbrich, I. M., Grieshop, A. P., Robinson, A. L., Duplissy, J., Smith, J. D., Wilson, K. R., Lanz, V. A., Hueglin, C., Sun, Y. L., Tian, J., Laaksonen, A., Raatikainen, T., Rautiainen, J., Vaattovaara, P., Ehn, M., Kulmala, M., Tomlinson, J. M., Collins, D. R., Cubison, M. J., Dunlea, E. J., Huffman, J. A., Onasch, T. B., Alfarra, M. R., Williams, P. I., Bower, K., Kondo, Y., Schneider, J., Drewnick, F., Borrmann, S., Weimer, S., Demerjian, K., Salcedo, D., Cottrell, L., Griffin, R., Takami, A., Miyoshi, T., Hatakeyama, S., Shimono, A., Sun, J. Y., Zhang, Y. M., Dzepina, K., Kimmel, J. R., Sueper, D., Jayne, J. T., Herndon, S. C., Trimborn, A. M., Williams, L. R., Wood, E. C., Middlebrook, A. M., Kolb, C. E., Baltensperger, U., and Worsnop, D. R.: Evolution of Organic Aerosols in the Atmosphere, Science, 326, 1525-1529, doi:10.1126/science.1180353, 2009.

Johansson, C. and Janson, R.: The diurnal cycle of $\mathrm{O}_{3}$ and monoterpenes in a coniferous forest: importance of atmospheric stability, surface exchange and chemistry., J. Geophys. Res., 98, 51215133, 1993.

Jonson, J. E., Simpson, D., Fagerli, H., and Solberg, S.: Can we explain the trends in European ozone levels?, Atmos. Chem. Phys., 6, 51-66, doi:10.5194/acp-6-51-2006, 2006.

Jonsson, A. M., Appelberg, G., Harding, S., and Barring, L.: Spatiotemporal impact of climate change on the activity and voltinism of the spruce bark beetle, Ips typographus, Global Change Biol., 15, 486-499, doi:10.1111/j.1365-2486.2008.01742.x, 2009.

Joutsensaari, J., Loivamäki, M., Vuorinen, T., Miettinen, P., Nerg, A.-M., Holopainen, J. K., and Laaksonen, A.: Nanoparticle formation by ozonolysis of inducible plant volatiles, Atmos. Chem. Phys., 5, 1489-1495, doi:10.5194/acp-5-1489-2005, 2005.

Juuti, S., Arey, J., and Atkinson, R.: Monoterpene emission rate measurements from a Monterey pine, J. Geophys. Res.-Atmos., 95, 7515-7519, doi:10.1029/JD095iD06p07515, 1990.

Kanakidou, M., Seinfeld, J. H., Pandis, S. N., Barnes, I., Dentener, F. J., Facchini, M. C., Van Dingenen, R., Ervens, B., Nenes, A., Nielsen, C. J., Swietlicki, E., Putaud, J. P., Balkanski, Y., Fuzzi, S., Horth, J., Moortgat, G. K., Winterhalter, R., Myhre, C. E. L., Tsigaridis, K., Vignati, E., Stephanou, E. G., and Wilson, J.: Organic aerosol and global climate modelling: a review, At- 
mos. Chem. Phys., 5, 1053-1123, doi:10.5194/acp-5-1053-2005, 2005.

Karl, M., Castell, N., Simpson, D., Solberg, S., Starrfelt, J., Svendby, T., Walker, S.-E., and Wright, R. F.: Uncertainties in assessing the environmental impact of amine emissions from a $\mathrm{CO}_{2}$ capture plant, Atmos. Chem. Phys., 14, 8533-8557, doi:10.5194/acp-14-8533-2014, 2014.

Karl, T., Guenther, A., Turnipseed, A., Patton, E. G., and Jardine, K.: Chemical sensing of plant stress at the ecosystem scale, Biogeosciences, 5, 1287-1294, doi:10.5194/bg-5-1287-2008, 2008.

Kaser, L., Karl, T., Guenther, A., Graus, M., Schnitzhofer, R., Turnipseed, A., Fischer, L., Harley, P., Madronich, M., Gochis, D., Keutsch, E. N., and Hansel, A.: Undisturbed and disturbed above canopy ponderosa pine emissions: PTR-TOF-MS measurements and MEGAN 2.1 model results, Atmos. Chem. Phys., 13, 11935-11947, doi:10.5194/acp-13-11935-2013, 2013.

Keenan, T., Niinemets, Ü., Sabate, S., Gracia, C., and Peñuelas, J.: Process based inventory of isoprenoid emissions from European forests: model comparisons, current knowledge and uncertainties, Atmos. Chem. Phys., 9, 4053-4076, doi:10.5194/acp-94053-2009, 2009.

Kiendler-Scharr, A., Wildt, J., Dal Maso, M., Hohaus, T., Kleist, E., Mentel, T. F., Tillmann, R., Uerlings, R., Schurr, U., and Wahner, A.: New particle formation in forests inhibited by isoprene emissions, Nature, 461, 381-384, doi:10.1038/nature08292, 2009a.

Kiendler-Scharr, A., Zhang, Q., Hohaus, T., Kleist, E., Mensah, A., Mentel, T. F., Spindler, C., Uerlings, R., Tillmann, R., and Wildt, J.: Aerosol Mass Spectrometric Features of Biogenic SOA: Observations from a Plant Chamber and in Rural Atmospheric Environments, Environ. Sci. Technol., 43, 8166-8172, doi:10.1021/es901420b, 2009b.

Kleist, E., Mentel, T. F., Andres, S., Bohne, A., Folkers, A., Kiendler-Scharr, A., Rudich, Y., Springer, M., Tillmann, R., and Wildt, J.: Irreversible impacts of heat on the emissions of monoterpenes, sesquiterpenes, phenolic BVOC and green leaf volatiles from several tree species, Biogeosciences, 9, 51115123, doi:10.5194/bg-9-5111-2012, 2012.

Kroll, J. H. and Seinfeld, J. H.: Chemistry of secondary organic aerosol: Formation and evolution of low-volatility organics in the atmosphere, Atmos. Environ., 16, 3593-3624, 2008.

Kuhn, M., Builtjes, P., Poppe, D., Simpson, D., Stockwell, W., Andersson-Sköld, Y., Baart, A., Das, M., Fiedler, F., Hov, Ø., Kirchner, F., Makar, P., Milford, J., Roemer, M., Ruhnke, R., Strand, A., Vogel, B., and Vogel, H.: Intercomparison of the gasphase chemistry in several chemistry and transport models, Atmos. Environ., 32, 693-709, 1998.

Lamarque, J. F., Bond, T. C., Eyring, V., Granier, C., Heil, A., Klimont, Z., Lee, D., Liousse, C., Mieville, A., Owen, B., Schultz, M. G., Shindell, D., Smith, S. J., Stehfest, E., Van Aardenne, J., Cooper, O. R., Kainuma, M., Mahowald, N., McConnell, J. R., Naik, V., Riahi, K., and van Vuuren, D. P.: Historical (1850-2000) gridded anthropogenic and biomass burning emissions of reactive gases and aerosols: methodology and application, Atmos. Chem. Phys., 10, 7017-7039, doi:10.5194/acp10-7017-2010, 2010.

Lane, T. E., Donahue, N. M., and Pandis, S. N.: Simulating secondary organic aerosol formation using the volatility basis-set approach in a chemical transport model, Atmos. Environ., 42, 7439-7451, doi:10.1016/j.atmosenv.2008.06.026, 2008.
Langner, J., Engardt, M., Baklanov, A., Christensen, J. H., Gauss, M., Geels, C., Hedegaard, G. B., Nuterman, R., Simpson, D., Soares, J., Sofiev, M., Wind, P., and Zakey, A.: A multi-model study of impacts of climate change on surface ozone in Europe, Atmos. Chem. Phys., 12, 10 423-10440, doi:10.5194/acp-1210423-2012, http://www.atmos-chem-phys.net/12/10423/2012/, 2012.

Lathiere, J., Hauglustaine, D., De Noblet-Ducoudre, N., Krinner, G., and Folberth, G.: Past and future changes in biogenic volatile organic compound emissions simulated with a global dynamic vegetation model, Geophys. Res. Lett., 32, doi:10.1029/2005GL024164, 2005.

Lee, A., Goldstein, A. H., Kroll, J. H., Ng, N. L., Varutbangkul, V., Flagan, R. C., and Seinfeld, J. H.: Gas-phase products and secondary aerosol yields from the photooxidation of 16 different terpenes, J. Geophys. Res., 111, D17305, doi:10.1029/2006JD007050, 2006.

Li, Y. P., Elbern, H., Lu, K. D., Friese, E., Kiendler-Scharr, A., Mentel, T. F., Wang, X. S., Wahner, A., and Zhang, Y. H.: Updated aerosol module and its application to simulate secondary organic aerosols during IMPACT campaign May 2008, Atmos. Chem. Phys., 13, 6289-6304, doi:10.5194/acp-13-6289-2013, 2013.

Lorenz, M.: Objectives, Strategy and Implementation of ICP Forests. Manual Part I, in: Manual on methods and criteria for harmonized sampling, assessment, monitoring and analysis of the effects of air pollution on forests., p. 21 pp., UNECE ICP Forests Programme Co-ordinating Centre, Hamburg, 2010.

Mentel, Th. F., Wildt, J., Kiendler-Scharr, A., Kleist, E., Tillmann, R., Dal Maso, M., Fisseha, R., Hohaus, Th., Spahn, H., Uerlings, R., Wegener, R., Griffiths, P. T., Dinar, E., Rudich, Y., and Wahner, A.: Photochemical production of aerosols from real plant emissions, Atmos. Chem. Phys., 9, 4387-4406, doi:10.5194/acp9-4387-2009, 2009.

Mentel, Th. F., Kleist, E., Andres, S., Dal Maso, M., Hohaus, T., Kiendler-Scharr, A., Rudich, Y., Springer, M., Tillmann, R., Uerlings, R., Wahner, A., and Wildt, J.: Secondary aerosol formation from stress-induced biogenic emissions and possible climate feedbacks, Atmos. Chem. Phys., 13, 8755-8770, doi:10.5194/acp-13-8755-2013, 2013.

Merilä, P., Kilponen, T., and Derome, J. (eds.): Forest Condition Monitoring in Finland - National Report 2002-2005, Working Papers of the Finnish Forest Research Institute 45, Finnish Forest Research Institute, http://www.metla.fi/julkaisut/ workingpapers/, 2007.

Minguillon, M. C., Perron, N., Querol, X., Szidat, S., Fahrni, S. M., Alastuey, A., Jimenez, J. L., Mohr, C., Ortega, A. M., Day, D. A., Lanz, V. A., Wacker, L., Reche, C., Cusack, M., Amato, F., Kiss, G., Hoffer, A., Decesari, S., Moretti, F., Hillamo, R., Teinila, K., Seco, R., Penuelas, J., Metzger, A., Schallhart, S., Mueller, M., Hansel, A., Burkhart, J. F., Baltensperger, U., and Prevot, A. S. H.: Fossil versus contemporary sources of fine elemental and organic carbonaceous particulate matter during the DAURE campaign in Northeast Spain, Atmos. Chem. Phys., 11, 12067 12084, doi:10.5194/acp-11-12067-2011, 2011.

Morales, P., Hickler, T., Rowell, D. P., Smith, B., and Sykes, M. T.: Changes in European ecosystem productivity and carbon balance driven by regional climate model output, Glob. Change Biol., 13, 108-122, 2007. 
Murphy, B. N. and Pandis, S. N.: Simulating the Formation of Semivolatile Primary and Secondary Organic Aerosol in a Regional Chemical Transport Model, Environ. Sci. Technol., 43, 4722-4728, doi:10.1021/es803168a, 2009.

Niinemets, U., Arneth, A., Kuhn, U., Monson, R. K., Penuelas, J., and Staudt, M.: The emission factor of volatile isoprenoids: stress, acclimation, and developmental responses, Biogeosciences, 7, 2203-2223, doi:10.5194/bg-7-2203-2010, 2010.

Peñuelas, J. and Staudt, M.: BVOCs and global change, Trends in Plant Sci., 15, 133-144, doi:10.1016/j.tplants.2009.12.005, 2010.

Riipinen, I., Pierce, J. R., Yli-Juuti, T., Nieminen, T., Häkkinen, S., Ehn, M., Junninen, H., Lehtipalo, K., Petäjä, T., Slowik, J., Chang, R., Shantz, N. C., Abbatt, J., Leaitch, W. R., Kerminen, V.-M., Worsnop, D. R., Pandis, S. N., Donahue, N. M., and Kulmala, M.: Organic condensation: a vital link connecting aerosol formation to cloud condensation nuclei $(\mathrm{CCN})$ concentrations, Atmos. Chem. Phys., 11, 3865-3878, doi:10.5194/acp-11-38652011, 2011.

Rinne, J., Markkanen, T., Ruuskanen, T. M., Petäjä, T., Keronen, P., Tang, M., Crowley, J. N., Rannik, U., and Vesala, T.: Effect of chemical degradation on fluxes of reactive compounds - a study with a stochastic Lagrangian transport model, Atmos. Chem. Phys., 12, 4843-4854, doi:10.5194/acp-12-4843-2012, 2012.

Sakalli, A. and Simpson, D.: Towards the use of dynamic growing seasons in a chemical transport model, Biogeosciences, 9, 51615179, doi:10.5194/bg-9-5161-2012, 2012.

Schade, G. and Goldstein, A.: Increase of monoterpene emissions from a pine plantation as a result of mechanical disturbances, Geophys. Res. Lett., 30, doi:10.1029/2002GL016138, 2003.

Schell, B., Ackermann, I. J., Hass, H., Binkowski, F., and Ebel, A.: Modeling the formation of secondary organic aerosol within a comprehensive air quality model system, J. Geophys. Res., 106, 28275-28293, 2001.

Schnitzler, J.-P., Louis, S., Behnke, K., and Loivamäki, M.: Poplar volatiles - biosynthesis, regulation and (eco)physiology of isoprene and stress-induced isoprenoids, Plant Biol., 12, 302-316, 2010.

Shrivastava, M. K., Lane, T. E., Donahue, N. M., Pandis, S. N., and Robinson, A. L.: Effects of gas particle partitioning and aging of primary emissions on urban and regional organic aerosol concentrations, J. Geophys. Res., 113, doi:10.1029/2007JD009735, 2008.

Simpson, D., Winiwarter, W., Börjesson, G., Cinderby, S., Ferreiro, A., Guenther, A., Hewitt, C. N., Janson, R., Khalil, M. A. K., Owen, S., Pierce, T. E., Puxbaum, H., Shearer, M., Skiba, U., Steinbrecher, R., Tarrasón, L., and Öquist, M. G.: Inventorying emissions from Nature in Europe, J. Geophys. Res., 104, 81138152, 1999.

Simpson, D., Fagerli, H., Hellsten, S., Knulst, J. C., and Westling, O.: Comparison of modelled and monitored deposition fluxes of sulphur and nitrogen to ICP-forest sites in Europe, Biogeosciences, 3, 337-355, doi:10.5194/bg-3-337-2006, 2006.

Simpson, D., Yttri, K., Klimont, Z., Kupiainen, K., Caseiro, A., Gelencsér, A., Pio, C., and Legrand, M.: Modeling Carbonaceous Aerosol over Europe. Analysis of the CARBOSOL and EMEP EC/OC campaigns, J. Geophys. Res., 112, D23S14, doi:10.1029/2006JD008158, 2007.
Simpson, D., Benedictow, A., Berge, H., Bergström, R., Emberson, L. D., Fagerli, H., Flechard, C. R., Hayman, G. D., Gauss, M., Jonson, J. E., Jenkin, M. E., Nyíri, A., Richter, C., Semeena, V. S., Tsyro, S., Tuovinen, J.-P., Valdebenito, A., and Wind, P.: The EMEP MSC-W chemical transport model - technical description, Atmos. Chem. Phys., 12, 7825-7865, doi:10.5194/acp12-7825-2012, 2012.

Szidat, S., Jenk, T.M .and. Gäggler, H., Synal, H.-A., Fisseha, R., Baltensperger, U., Kalberer, M., Samburova, V., Reimann, S., Kasper-Giebl, A., and Hajdas, I.: Radiocarbon $\left({ }^{14} \mathrm{C}\right)$-deduced biogenic and anthropogenic contributions to organic carbon (OC) of urban aerosols from Zürich, Switzerland, Atmos. Environ., 38, 4035-4044, 2004.

Szidat, S., Ruff, M., Perron, N., Wacker, L., Synal, H.-A., Hallquist, M., Shannigrahi, A. S., Yttri, K. E., Dye, C., and Simpson, D.: Fossil and non-fossil sources of organic carbon (OC) and elemental carbon (EC) in Göteborg, Sweden, Atmos. Chem. Phys., 9, 1521-1535, doi:10.5194/acp-9-1521-2009, 2009.

Tunved, P., Ström, J., Kulmala, M., Kerminen, V. M., Dal Maso, M., Svenningson, B., Lunder, C., and Hansson, H. C.: The natural aerosol over Northern Europe and its relation to anthropogenic emissions - implications of important climate feedbacks, Tellus, 60, 473-484, doi:10.1111/j.1600-0889.2008.00363.x, 2008.

VanReken, T. M., Greenberg, J. P., Harley, P. C., Guenther, A. B., and Smith, J. N.: Direct measurement of particle formation and growth from the oxidation of biogenic emissions, Atmos. Chem. Phys., 6, 4403-4413, doi:10.5194/acp-6-4403-2006, 2006.

Volkamer, R., Jimenez, J. L., Martini, F. S., Dzepina, K., Zhang, Q., Salcedo, D., Molina, L. T., Worsnop, D. R., and Molina, M. J.: Secondary organic aerosol formation from anthropogenic air pollution: Rapid and higher than expected, Geophys. Res. Lett., 33, L17811, doi:10.1029/2006GL026899, 2006.

Vuorinen, T., Nerg, A.-M., Syrjälä, L., Peltonen, P., and Holopainen, J. K.: Epirrita autumnata induced VOC emission of silver birch differ from emission induced by leaf fungal pathogen, Arthropod-Plant Inte., 1, 159-165, 2007.

Wiedinmyer, C., Akagi, S. K., Yokelson, R. J., Emmons, L. K., AlSaadi, J. A., Orlando, J. J., and Soja, A. J.: The Fire INventory from NCAR (FINN): a high resolution global model to estimate the emissions from open burning, Geosci. Model Dev., 4, 625641, doi:10.5194/gmd-4-625-2011, 2011.

Wildermuth, M. C.: Variations on a theme: synthesis and modification of plant benzoic acids, Curr. Opin. Plant Biol., 9, 288-296, 2006.

Winterhalter, R., Herrmann, F., Kanawati, B., Nguyen, T. L., Peeters, J., Vereecken, L., and Moortgat, G. K.: The gasphase ozonolysis of beta-caryophyllene $\left(\mathrm{C}_{15} \mathrm{H}_{24}\right)$. Part I: an experimental study, Phys. Chem. Chem. Phys., 11, 4152-4172, doi:10.1039/b817824k, 2009.

Yttri, K. E., Simpson, D., Nøjgaard, J. K., Kristensen, K., Genberg, J., Stenström, K., Swietlicki, E., Hillamo, R., Aurela, M., Bauer, H., Offenberg, J. H., Jaoui, M., Dye, C., Eckhardt, S., Burkhart, J. F., Stohl, A., and Glasius, M.: Source apportionment of the summer time carbonaceous aerosol at Nordic rural background sites, Atmos. Chem. Phys., 11, 13339-13357, doi:10.5194/acp11-13339-2011, 2011. 